\title{
Back to your heart: Ubiquitin proteasome system-regulated signal transduction
}

\author{
Andrea L. Portbury ${ }^{1}$, Sarah M. Ronnebaum ${ }^{1}$, Makhosazane Zungu ${ }^{2}$, Cam Patterson ${ }^{1,3}$, and \\ Monte S. Willis ${ }^{1,2,}$ \\ ${ }^{1}$ McAllister Heart Institute, University of North Carolina, Chapel Hill, NC USA \\ ${ }^{2}$ Department of Pathology \& Laboratory Medicine, University of North Carolina, Chapel Hill, NC \\ USA \\ ${ }^{3}$ Departments of Cell and Developmental Biology, Medicine, and Pharmacology, University of \\ North Carolina, Chapel Hill, NC
}

\begin{abstract}
Awareness of the regulation of cell signaling by post-translational ubiquitination has emerged over the past 2 decades. Like phosphorylation, post-translational modification of proteins with ubiquitin can result in the regulation of numerous cellular functions, for example, the DNA damage response, apoptosis, cell growth, and the innate immune response. In this review, we discuss recently published mechanisms by which the ubiquitin proteasome system regulates key signal transduction pathways in the heart, including MAPK JNK, calcineurin, FOXO, p53, and estrogen receptors $\alpha$ and $\beta$. We then explore how ubiquitin proteasome system-specific regulation of these signal transduction pathways plays a role in the pathophysiology of common cardiac diseases, such as cardiac hypertrophy, heart failure, ischemia reperfusion injury, and diabetes.
\end{abstract}

\section{Keywords}

Ubiquitin; proteasome; JNK; c-Jun; calcineurin; FOXO; p53; estrogen receptor; cardiac hypertrophy; ischemia; diabetes

\section{Introduction}

Over the past 2 decades, our understanding of the role of ubiquitination in regulating cell signaling has evolved. Like phosphorylation, post-translational modification of proteins with ubiquitin can result in the regulation of numerous cellular functions, such as the DNA damage response, apoptosis, cell growth, and the innate immune response. Recently, studies have described how ubiquitination in the heart regulates key signaling transduction pathways important in common cardiac diseases, including cardiac hypertrophy, heart

\footnotetext{
(C) 2011 Elsevier Ltd. All rights reserved.

"Correspondence and inquiries to: Monte S. Willis, M.D., Ph.D., McAllister Heart Institute, University of North Carolina at Chapel Hill, 2340B Medical Biomolecular Research Building, 103 Mason Farm Road; Chapel Hill, NC 27599-7525, Phone: (919) 843-1938, Fax: (919) 843-4585, monte_willis@med.unc.edu.

Publisher's Disclaimer: This is a PDF file of an unedited manuscript that has been accepted for publication. As a service to our customers we are providing this early version of the manuscript. The manuscript will undergo copyediting, typesetting, and review of the resulting proof before it is published in its final citable form. Please note that during the production process errors may be discovered which could affect the content, and all legal disclaimers that apply to the journal pertain.

Disclosures

None of the authors have any conflict of interest to declare.
} 
failure, ischemia reperfusion injury, and diabetes. In this review, we explore the mechanisms by which the ubiquitin proteasome system (UPS) specifically regulates signal transduction and then put into context how these mechanisms may influence the pathophysiology of common cardiac diseases. This is an emerging and vast field of study and, as such, it is not been possible to cover all aspects in depth. However, this review represents a comprehensive overview of new and exciting data as they relate to the heart.

\section{Ubiquitination is a multi-step process that occurs at several levels of signal transduction}

The placement of ubiquitin on specific protein substrates is regulated by three enzymes: E1 (ubiquitin-activating); E2 (ubiquitin-conjugating); and E3 (ubiquitin ligase). The specificity of the ubiquitination process is afforded by the ubiquitin ligase (of which over 500 have been identified) which recognizes and interacts with specific substrates on to which ubiquitin is then attached. Ubiquitin attaches to the substrate via an isopeptide bond between the C-terminus of ubiquitin and a lysine residue on the substrate. Since ubiquitin itself contains 7 lysines (K6, K11, K27, K29, K33, K48, and K63) ubiquitin can also bind to other ubiquitin molecules, thereby forming a ubiquitin chain on the targeted substrate. The fate of the ubiquitinated substrate depends on which lysine residue the attached ubiquitin chain is formed. Canonical ubiquitin chains bind via K48 residues and are recognized by the proteasome which targets the ubiquitinated substrate for degradation. Other polyubiquitin chains, such as the K63-linked chains, generally affect substrate activity via non-proteolytic mechanisms [1-4]. However, these atypical ubiquitin chains may also be involved in protein degradation depending on the context and presence of other types of ubiquitin chains that are also present on the substrate [5-7]. However, not every ubiquitination reaction results in the formation of a ubiquitin chain on a 4 substrate. In some instances, a single ubiquitin molecule will be added to a substrate (monoubiquitination), resulting in an alteration in the activity of the substrate without leading to its degradation. For example, monoubiquitination regulates nuclear localization and activity of transcription factors, gene expression (via histones), endocytosis, and trafficking of receptors, transporters, and channels [8-10]. With hundreds of ubiquitin ligases identified, each specific for a handful of target proteins, it is not surprising that some of these targets are involved in signaling transduction pathways, the ubiquitination of which results in both stimulation and inhibition of downstream signaling. Here we present emerging evidence that the UPS regulates signaling occurring through the MAPK JNK, calcineurin, FOXO, p53, and the estrogen receptors $\alpha$ and $\beta$. We then discuss this regulation in the context of common cardiac diseases.

\section{The UPS regulates JNK signaling in the heart}

\section{JNK signaling in the heart}

Activation of the JNK signaling pathways occurs in response to different stimuli, including inflammatory cytokines and stressors such as ischemia reperfusion (I/R), UV radiation, oxidant stress, hyperosmolality, ER stress, and DNA damage [11, 12]. G protein-coupled receptors, growth factors, and non-canonical Wnt signaling are also known to induce the activation of JNK signaling [13, 14], the latter being critical in cardiac development [15]. During early heart development, non-canonical Wnt signaling involving activation of the JNK signaling pathway has been implicated in the determination of cardiac cell fate and morphogenesis of the developing heart, including proper development of the outflow tract $[16,17]$.

In the context of cardiac disease, JNK signaling is activated in response to I/R injury [18, 19]. Cells within the myocardium undergo apoptosis in response to $I / R$ injury and the intracellular pathways through which ischemia induces cell death and other "stress 
responses" in cardiomyocytes have been extensively characterized. In addition to activating the JNK signaling pathway, cardiac I/R also activates the $\mathrm{p} 38$ mitogen-activated protein kinase pathway $[18,19]$. The p38 MAPK signaling pathway is activated during ischemia and is maintained in an activated state during reperfusion [11, 20]. In contrast, signaling through the JNK pathway is the only MAPK pathway generally activated during reperfusion, resulting in the activation of the AP-1 transcription factor and subsequent cellular apoptosis [21-23], making it a unique pathway during I/R-induced apoptosis.

\section{Regulation of JNK signal transduction by ubiquitination and SUMOylation}

There is growing evidence that ubiquitination plays a role in regulating MAPK signaling in general, and JNK signaling in particular [24], and recent studies have identified cardiacspecific ubiquitin ligases (E3) that regulate JNK signaling in vivo (described below) [25] [26]. Post-translational modification of JNK signaling intermediaries with ubiquitin [24] and ubiquitin-like proteins $[27,28]$ inhibits JNK signaling by interacting with and inhibiting activated c-Jun in both cardiac and non-cardiac cells. At least 6 proteins with ubiquitin ligase activity have been linked to regulation of JNK signaling: MEKK1 [29, 30], Fbw7 [31], DCX ${ }^{\mathrm{hDET1}}$-hCOP1 [32], itch [33], MuRF1 [25], and atrogin-1/MAFbx [26], with the latter 2 recently implicated in regulation of JNK signaling in the heart.

MEKK1 is a MAP3K in the JNK signaling pathway that has protein kinase activity allowing the downstream activation of MAP2Ks, which in turn activate JNK (see Figure 1)[15]. What makes MEKK1 unique among MAP3Ks is that it also has ubiquitin ligase activity, which therefore also allows it to inhibit JNK signaling downstream. Specifically, MEKK1 recognizes and polyubiquitinates phosphorylated c-Jun, which is then degraded by the $26 \mathrm{~S}$ proteasome to effectively inhibit JNK signaling [29, 30]. In osmotic stress-induced cell death in NIH 3T3 cells, MEKK1 exhibits ubiquitin ligase activity toward phosphorylated cJun through its PHD/RING finger domain [30]. Similarly, in neuronal cells, the ubiquitin ligase Fbw7 ubiquitinates phosphorylated c-Jun and facilitates c-Jun degradation [31], whereas depletion of Fbw7 results in the accumulation of phosphorylated c-Jun, enhanced AP-1 activity, and increased neuronal apoptosis [31]. In this way, Fbw7 potently antagonizes the apoptotic JNK signaling pathways, allowing neurons to tolerate (i.e. to be protected) from neurotoxic JNK activation [31]. In addition to MEKK1 and Fbw7, two other ubiquitin ligases, DCX ${ }^{\mathrm{hDET} 1-\mathrm{hCOP} 1}$ and itch, also target c-Jun for ubiquitin-mediated degradation $[34,35]$.

The ubiquitin ligases DCX $\mathrm{hDET1}^{\mathrm{hCOP} 1}$ and itch were initially reported to regulate JNK signaling in cancer cell lines and T cells, respectively $[36,37]$. The DCX ${ }^{\mathrm{hDET} 1-\mathrm{hCOP} 1}$ complex is made up 5 subunits: human De-etiolated-1 (hDET-1), human constitutively photomorphogenic 1 (hCOP1), DNA Damage Binding Protein-1 (DDB1), cullin 4A (CUL4A) and Regulator of Cullins-1 (ROC1) [32]. In HEK293T cells, DCX ${ }^{\text {hDET1-hCOP1 }}$ interacts with cJun, targeting it for degradation in a proteasome-dependent manner [32]. In both HEK293T and U2OS cells, reducing DCX ${ }^{\mathrm{hDET} 1-\mathrm{hCOP} 1}$ levels enhances c-Jun activity (measured through AP-1 activity) whereas increasing DCX ${ }^{\mathrm{hDET} 1-\mathrm{hCOP} 1}$ levels inhibits AP-1 activity [32]. The ubiquitin ligase itch accumulates in T cells from mice lacking the protein Itch, characterized by their constantly itching of the skin [37]. The HECT domain of Itch functions in the ubiquitin-dependent degradation of both cJun and JunB, which accumulated in the T cells of Itchy mice [37]. The name of this ubiquitin ligase was founded due to the observation that mice in which this protein is disrupted exhibit severe itching and systemic dysregulation of the immune system [38]. It was later determined that the itchy phenotype in these mice is likely due to excessive cytokine production from $\mathrm{T}$ cells (specifically $\mathrm{TH} 2$ cells) [37], a phenotype that is also exhibited by mice lacking JNK [39, 40]. Subsequent studies identified that Itch regulated the turnover of cJun/JunB resulting in the dysregulation of IL-4 in T cells [33]. The number of ubiquitin ligases able to inhibit JNK indicates the 
possible need for redundancy and inhibition at multiple levels in response to pathophysiologic stimuli. It may additionally indicate a tissue specificity of these systems, a concept that has not been investigated widely to date.

In addition to ubiquitin-mediated regulation of activity, c-Jun can also be regulated by posttranslational modification of proteins with SUMO (포all ubiquitin-like modifier), whereby ubiquitin ligases place SUMO modifications (rather than ubiquitin molecules) on c-Jun. Sumoylation of target substrates does not result in substrate degradation, however it does affect the ability of the substrate to move within the intracellular milieu [41]. In the case of c-Jun, ubiquitin-like SUMO-1 post-translational modification in non-cardiomyocyte cell lines restricts the localization of c-Jun to the nucleus, which in turn negatively regulates its activation of AP-1, without interfering with c-Jun's ubiquitination state or steady state levels of protein [42]. Similar to the case of ubiquitination of c-Jun, SUMO-1 post-translational modification is enhanced when c-Jun is phosphorylated.

\section{Ubiquitin-mediated regulation of JNK signaling in cardiac I/R injury}

Like the regulation of JNK signaling in other cell types, recent studies have demonstrated that the heart also contains ubiquitin ligases capable of regulating JNK signaling. Specifically, MuRF1, a striated muscle-specific ubiquitin ligase, ubiquitinates intermediaries in the JNK signaling pathway to inhibit them [25]. Like MEKK1, MuRF1 interacts with cJun preferentially when phosphorylated, resulting in its polyubiquitinatation and subsequent proteasomal degradation [25]. This in turn inhibits downstream AP-1 activity, which, among other things, leads to a decrease in apoptosis [25]. In the H9C2 cardiac derived cell line, increasing MuRF1 protects against simulated I/R injury-induced apoptosis [25]. Conversely, knocking down MuRF1 expression with siRNA enhances AP-1 activity and subsequent apoptosis in this system. MuRF1 is also cardioprotective in the hearts of MuRF1 Tg+ mice (in which cardiac MuRF1 is selectively overexpressed) challenged with both global I/R injury and $\mathrm{I} / \mathrm{R}$ induced by occlusion of the left anterior descending coronary artery in vivo [25]. In these mice, recovery from decreased cardiac function caused by global I/R injury is significantly heightened compared to wild-type mice [25]. Similarly, MuRF1 Tg+ mice exhibit a significant reduction in the ratio of area of infarct/area of risk ( $10 \%$ affected area vs. $25 \%$ in wild-type animals) as well as a decrease in functional deficits (determined by echocardiography) following occlusion of the left anterior descending coronary artery in vivo [25]. The decrease in damage and functional deficits in the hearts of MuRF1 Tg+ mice correlates with a decrease in phospho-c-Jun (but not in other MAPK pathway components such as phospho-ERK1/2 or phospho-p38) [25]. Consistent with these findings, pretreatment of MuRF1 Tg + Mice with the JNK inhibitor SP600125 abolishes the differential cardioprotection of increased expression of cardiac MuRF1, illustrating again the impact of MuRF1's regulation of the JNK signaling pathway in controlling damage associated with cardiac I/R injury.

Atrogin-1/MAFbx, another muscle-specific ubiquitin ligase, also regulates JNK signaling in the heart. However, unlike MEKK1 and MuRF1, atrogin-1/MAFbx enhances JNK signaling by ubiquitinating the JNK phosphatase, thereby mediating its proteasomal degradation. Degradation of JNK phosphatase increases the amount of phosphorylated/activated c-Jun, resulting in the enhancement of downstream AP-1 activity [26]. As such, unlike MuRF1's protective influence 8 over I/R injury, atrogin-1/MAFbx enhances cardiac susceptibility to simulated I/R injury in vitro [26]. Increasing atrogin-1/MAFbx expression in the cardiacderived cell line $\mathrm{H} 9 \mathrm{C} 2$ enhances I/R-induced apoptosis as determined by TUNEL staining. In addition, increasing expression of atrogin-1/MAFbx in $\mathrm{H} 9 \mathrm{C} 2$ cells after $\mathrm{I} / \mathrm{R}$ decreases the level of the anti-apoptotic protein Bcl-2, and increases the pro-apoptotic proteins Bax, cleaved caspase-9, and cleaved caspase-3. Conversely, knocking down atrogin-1/MAFbx and challenging cardiomyocytes to I/R injury results in protection against apoptosis [26]. 
The pro-apoptotic effect of atrogin-1/MAFbx in I/R injured H9C2 cells is mediated in part by atrogin-1/MAFbx's ubiquitination of MKP-1, which results in its degradation and subsequent enhancement of JNK-mediated apoptosis. Together, these studies illustrate how the UPS regulates JNK signaling in the context of protein kinase regulation of I/R mediated injury in the heart.

\section{UPS regulation of calcineurin signaling}

\section{Calcineurin Signaling in the heart}

Calcineurin, also referred to as protein phosphatase 2B (PP2B), is a calcium-sensitive protein that dynamically responds to cardiac stress. Originally identified by its calcium binding properties in neuronal tissue [43], calcineurin has since been shown to play an important role in heart development, maintenance, and stress responses. The main target of calcineurin's phosphatase activity is the transcription factor NFAT, which translocates to the nucleus following calcineurin-dependent dephosphorylation [44]. In cardiomyocytes, NFAT associates with transcription factors such as GATA4 and MEF2 [45, 46]. NFAT activity leads to transcription of genes such as $\alpha$-actin, endothelin-1, atrial natriuretic factor (ANF), and $\beta$-myosin heavy chain, which promote hypertrophic growth pathways associated with the fetal gene programming [47]

\section{Regulation of calcineurin signal transduction by ubiquitination}

Because calcineurin's main molecular target is NFAT, calcineurin signaling can be blunted by proteins that target NFAT. The kinases DYRK1A, DYRK2, GSK3B, and CK1 have each been shown to inhibit NFAT activity by phosphorylation that leads to NFAT nuclear exclusion $[48,49]$. This phosphorylation also appears to promote NFAT degradation in a ubiquitin-dependent manner [50]. In cell culture, NFAT protein levels and transcriptional activity are inversely proportional to the abundance of wild-type ubiquitin, whereas overexpression of a mutant form of ubiquitin that cannot form canonical chains has no effect on the levels of NFAT [50]. Likewise, NFAT protein levels increase dramatically in cells treated with a proteasome inhibitor, suggesting that proteasomal degradation of NFAT is a method by which cells regulate the level of this protein [50]. In cardiomyocytes, overexpression of constitutively-active GSK3 $\beta$ increases NFAT turnover and decreases NFAT transcriptional activity, whereas phenylephrine administration, which activates calcineurin, appears to prevent NFAT ubiquitination and increase NFAT transcriptional activity [50]. Although the exact mechanism by which GSK3 $\beta$ regulates NFAT protein level and activity is not clear, it has been suggested that GSK3 $\beta$-mediated phosphorylation improves NFAT recognition by an as yet unidentified ubiquitin ligase [50].

\section{Cardiac-specific regulation of calcineurin signaling by the UPS}

In the heart, the ubiquitin ligase atrogin-1/MAFbx inhibits calcineurin activity through two distinct mechanisms. First atrogin-1/MAFbx activates FoxO transcriptional activity through atypical (K63) ubiquitination (discussed below), thereby repressing calcineurin-dependent cardiac hypertrophy [51]. Second, atrogin-1/MAFbx associates with Cul1, Roc1, and Skp1 to ubiquitinate and degrade calcineurin, attenuating agonist-induced calcineurin activity, hypertrophy, activation and nuclear translocation of NFAT and subsequent fetal gene expression profile associated with hypertrophy $[52,53]$. Transgenic mice in which cardiac expression of atrogin-1/MAFbx is increased have normal baseline cardiac function but are resistant to pressure overload-induced cardiac hypertrophy [53]. Despite the lack of hypertrophic response, these mice do develop pathological changes associated with pressure overload, specifically significant thinning of the left ventricular wall, resulting in dilation of the ventricle, an increase in left ventricular end systolic dimensions and a decrease in 
ejection fraction, demonstrating the importance of a balance between protein synthesis and degradation mechanisms in cardiac pressure overload.

\section{Proteasomal inhibition and calcineurin/NFAT signaling in cardiomyocytes}

In cultured cardiomyocytes, knockdown of atrogin-1/MAFbx with siRNA results in enhanced calcineurin expression and phosphatase activity as well as agonist-induced hypertrophy [53]. Mice treated with the proteasome inhibitor MG626 for 24 hrs exhibit increased NFAT activity, but no change in calcineurin activity [54]. However, cardiomyocytes treated with MG626 display an increase in nuclear NFAT translocation that is dependent on calcineurin activity. When cells are stimulated with norepinephrine, to induce hypertrophy, in the presence of MG262, cells increase in length, but not in width, a characteristic commonly associated with cardiomyocytes underlying chamber dilation in chronic heart failure [55]. When mice are treated with the proteasome inhibitor Bortezomib, they develop cardiac hypertrophy equivalent to what is seen when mice undergo TAC. When proteasome inhibition is induced in conjunction with pressure overload, lethality is increased (compared to TAC treatment alone) and increased signs of left ventricular dilation and dysfunction are evident [54].

\section{The role of proteasomal regulation of calcineurin/NFAT signaling in desmin-related cardiomyopathy}

In cardiomyocytes isolated from D7-des transgenic mice (a mouse model of desmin-related cardiomyopathy), calcineurin protein levels are increased, as is NFAT activity [54]. Interestingly, MT-des, a mutant form of the desmin protein that has been linked to desminrelated cardiomyopathy [56] increases calcineurin protein expression in cultured cardiomyocytes [54]. This, together with evidence of proteasomal insufficiency in desminrelated cardiomyopathy [57] offers an explanation for the cardiac hypertrophy and subsequent heart failure associated with this condition.

\section{UPS regulation of FoxO Signaling}

\section{FoxO signaling in the heart}

FoxOs are a subfamily of the Forkhead winged helix transcription factor superfamily, which recognize a DNA binding domain referred to as the Forkhead box (Fox). The FoxO family of transcription factors plays an important role in the development, maintenance, and stress response of the heart. Several members of the FoxO family (including FoxC1, FoxC2, FoxO1 and FoxP1) are critical during cardiogenesis: mice in which these proteins have been deleted exhibit severe arterial and cardiac defects and early lethality [58]. In the mature animal, FoxO1, FoxO3, and FoxO4 play overlapping and complementary roles in the heart by transcribing genes involved in oxidative stress response, hypertrophy prevention, and metabolic regulation [59]. Given this expansive repertoire of functions, it is not surprising that FoxO signaling is regulated by numerous post-translational modifications such as phosphorylation, glycosylation, acetylation and ubiquitination [60].

\section{Regulation of cardiac FoxO signal transduction}

FoxO activity is regulated by AKT, also known as protein kinase $\mathrm{B}$. In the heart, the AKT signaling pathway is activated by increased cardiac demand due to exercise training, pressure overload, and nutrition status [60, 61]. Signaling through the insulin/IGF receptor tyrosine kinase, integrins, and some G-protein coupled receptors activates PI3K, which generates PIP3 at the plasma membrane [62]. PIP3 production recruits AKT to the plasma membrane, where AKT is phosphorylated and activated by PDK1 [63] and mTOR [64] at T308 and S473, respectively. Activated AKT can then phosphorylate a plethora of targets that are generally involved in cell growth and apoptosis evasion. AKT phosphorylation also 
allows AKT to enter the nucleus, where it phosphorylates FoxO [65]. This phosphorylation serves two purposes: it masks a FoxO nuclear localization sequence [66] and stimulates association between FoxO and a subset of nuclear 14-3-3 proteins, causing FoxO nuclear export, cytosolic sequesterization, and activity inhibition (see Figure 2) [67, 68].

\section{Regulation of FoxO activity by ubiquitination}

Once in the cytosol, AKT-phosphorylated FoxO1/3 is susceptible to proteasome-mediated degradation [69]. AKT's phosphorylation of FoxO1 at S256 permits FoxO1 to associate with Skp2, the main ubiquitin ligase targeting FoxO1, which leads to FoxO1 polyubiquitination and degradation [70]. In a similar manner, FoxO1 S256 phosphorylation in smooth muscle cells allows association with the ubiquitin ligase CHIP (also called Stub1), subsequently leading to FoxO1 degradation [71]. Other kinases can promote FoxO degradation via phosphorylation at different residues. FoxO3 phosphorylation by ERK at S294, S344, and S425 leads to association with the ubiquitin ligase MDM2, causing FoxO3 polyubiquitination and degradation [72], while IкB-dependent phosphorylation at S644 also leads to FoxO3 polyubiquitination and degradation [73]. Finally, COP1, an insulin-regulated ubiquitin ligase that is involved in mammalian cell survival, growth and metabolism, degrades FoxO1 resulting in a reduction of FoxO1-target genes such as glucose-6phosphatase and phosphoenolpyruvate carboxykinase, both of which play an important role in gluconeogenesis [74] (see Figure 3).

FoxO activity can also be regulated via monoubiquitination. However, unlike polyubiquitination that results in the degradation of FoxO, monoubiquitination causes an increase in FoxO activity. Following the onset of oxidative stress, FoxO4 is monoubiquitinated by MDM2, which increases FoxO4 nuclear localization and transcriptional activity (see Figure 3) [75]. However, this modification can be reversed by the activity of the deubiquitinating enzyme USP7, which increases FoxO4 nuclear export without affecting FoxO half-life [76]. Additionally, oxidative stress causes FoxO4 to interact with Pin1, which enhances the recognition of monoubiquitinated FoxO4 by USP7 to diminish FoxO4 transcriptional activity [75] .

\section{Ubiquitin-mediated regulation of FoxO signaling in the heart}

In cardiomyocytes, atrogin-1/MAFbx suppresses the phosphorylation of FoxO1 and FoxO3 induced by either IGF-1 or insulin [52]. In addition, atrogin-1/MAFbx induces the nuclear translocation of FoxO1 and FoxO3a and acts as a transactivator (independent of its role in sequestering FoxO proteins in the nucleus) to enhance transcriptional activity of FoxO [52]. In order to affect these changes in FoxO location and activity, atrogin-1/MAFbx ubiquitinates the FoxO proteins in a noncanonical manner using lysine 63-linked chains. This results in ubiquitination of the FoxO proteins but no subsequent proteasomal degradation. Since atrogin-1/MAFbx is one of the target proteins of FoxO activation (see Figure 3), enhancement of FoxO's transcriptional activity by this noncanonical ubiquitination results in increased expression of atrogin-1/MAFbx, thereby forming a positive feedback loop [52]. The in vivo significance of atrogin-1/MAFbx's ubiquitination of FoxO is demonstrated in transgenic mice expressing increased levels of cardiac-specific atrogin-1/MAFbx . In these mice, injection of IGF-1 to stimulate AKT-dependent cardiac hypertrophy results in decreased levels of phosphorylated FoxO1 and FoxO3a and concomitant increased expression of the FoxO target genes Bim, p27kip1, GADD45, and SOD2 [52]. In addition, increases in left ventricular mass are significantly inhibited in these mice, along with other parameters of cardiac hypertrophy. In contrast, when atrogin-1/ MAFbx-deficient mice are subjected to cardiac hypertrophy induced by voluntary wheel exercise, an exaggerated cardiac hypertrophic response is seen in comparison to wild-type mice [52]. Although the level of ubiquitinated cardiac FoxO has not been measured in this 
experimental setting, the correlation between atrogin-1/MAFbx levels and FoxO ubiquitination seen in cardiomyocytes in culture would suggest that atrogin-1/MAFbxdeficient mice would have decreased levels of noncanonically ubiquitinated cardiac FoxO proteins, which in turn, would lead to a decrease in activation of FoxO target genes known to promote catabolism, leading to the enhanced cardiac hypertrophy seen in these mice.

\section{The implication of possible ubiquitin-mediated regulation of FoxO signaling in cardiac disease}

An upregulation of cardiac FoxO expression has been reported associated with myocardial infarction, myocardial reperfusion injury, heart failure and myocyte hypertrophy [77-80]. For instance, FoxO signaling plays an important role in the response to myocardial infarction and I/R injury. In mice subjected to MI via left coronary artery ligature for 1-140 days, FoxO1 and FoxO3 levels are upregulated in concert with increased transcription of KATP channel subunits [81], which are involved in maintaining left ventricular function and protecting against heart failure. Furthermore, mice expressing a cardiomyocyte-specific FoxO1/FoxO3 deletion demonstrate decreases in fractional shortening and increases in ischemic area, fibrosis, and cell death when subjected to myocardial infarction [82].

Although studies like these indicate a role of FoxO signaling in cardiac disease mechanisms, a role for the ubiquitin-mediated regulation of FoxO signaling has not been implicated.

Nevertheless, such a scenario is feasible given that ubiquitin ligases known to regulate FoxO signaling in other situations (for example MDM2, atrogin-1/MAFbx and CHIP) have all been linked to conditions associated with cardiac disease and stress [26] [83, 84].

\section{UPS regulation of p53 signaling}

\section{p53 signaling in the heart}

p53 is a complex, multi-functional transcription factor that plays critical roles in cellular functions such as cell cycling, tumor suppression and maintaining DNA stability by preventing mutations. In the heart, a number of other functions have also been attributed to p53, including regulation of apoptosis, autophagy and angiogenesis, all of which have significance in cardiac disease. In addition, p53 has been linked to a number of cardiac pathologies such as pathologic cardiac hypertrophy, dilated cardiomyopathy, cardiac ischemic injury and cardiac disease associated with diabetes.

\section{Regulation of p53 signal transduction by ubiquitination}

The ubiquitin ligase MDM2 (murine double minute 2) regulates protein levels of p53 by ubiquitinating p53 via its RING domain [85, 86]. MDM2 catalyzes both mono- and polyubiquitination of p53. Monoubiquitination targets $\mathrm{p} 53$ for nuclear export in a dosedependent manner [87, 88]. During normal homeostasis, p53 drives the expression of MDM2, which in turn increases p53's ubiquitination, leading to an overall decrease in p53 protein levels. Conversely, when stress such as DNA damage occurs, p53 activity decreases, inhibiting MDM2 transcription and ubiquitin ligase activity, resulting in increased levels of p53 protein [89]. There are 6 lysines on p53 (see Figure 4) that are ubiquitinated by MDM2, including lysines $370,372,373,381,382$, and 386 [88, 90]. Despite the fact that MDM2 can reduce the amount of endogenous p53 in cells [89], there is also evidence that nondegradative mechanisms of ubiquitin-mediated regulation of p53 is also important. When the lysines on p53 are replaced with arginines to inhibit ubiquitination, p53 expression levels are not altered, suggesting that ubiquitination may have more of a regulatory role on p53 activity, as opposed to mediating its proteasomal degradation [91, 92]. Similarly, it has recently been reported that p53 can be ubiquitinated in its DNA binding domain (see Figure 4) [93]. Interestingly, removal of this domain significantly alters the stability of p53, without inhibiting all of its degradation, indicating that ubiquitination in this DNA binding domain is 
another method by which p53's activity is regulated, without leading to proteasomal degradation. The ubiquitin-mediated regulation of $\mathrm{p} 53$ activity by MDM2 is countered by the deubiquitinating activity of herpesvirus-associated ubiquitin-specific protease (HAUSP) [94].

MDM2 is not the only ubiquitin ligase involved in the regulation of p53 levels and activity [95]. Other ubiquitin ligases demonstrated to ubiquitinate p53 include: COP1, Pirh2, CHIP [96] TOPORS [97, 98], CARP1 and CARP2 [99], ARF-BP1 [100], CBP [101] and Synoviolin [102]. The fact that p53 can be regulated by all these proteins reflects the essential role $\mathrm{p} 53$ plays in stabilization of the cellular genetic machinery.

\section{Ubiquitin proteasome regulation of cardiac p53 signaling}

Elevated levels of cardiac p53 are associated with a number of cardiovascular conditions including heart failure, cardiac hypertrophy induced by pressure overload and dilated cardiomyopathy (DCM) [103] [104] [105]. In the case of DCM, a role for ubiquitinmediated regulation of p53 has also been found [105]. In hearts from patients with DCM, p53, MDM2, and HAUSP are all elevated compared to control, non-failing hearts. The fact that p53 is elevated even in the presence of increased levels of MDM2 suggests that the concurrent increase in HAUSP, the enzyme responsible for deubiquitinating p53 may be dominant in this situation. In addition to the increased levels of p53, MDM2 and HAUSP, hearts from patients with DCM also exhibit increased levels of ubiquitinated proteins in general, despite elevated levels of proteasomal activity, suggesting that the cardiac UPS in DCM is overwhelmed and unable to take care of the increase in ubiquitinated proteins, including $\mathrm{p} 53$.

In cardiomyocytes, endogenous p53 associates with CHIP (carboxyl-terminus of Hsp70interacting protein), and when CHIP is knocked down (using siRNA techniques) the expression level of p53 rises, indicating that CHIP functions to limit the level of p53 in cardiomyocytes [106]. Similarly, hearts isolated from CHIP heterozygous mice (that express approximately half the level of CHIP that wild-type mice express) exhibit increased levels of p53 expression, again demonstrating that CHIP functions to maintain a low level of p53 expression under physiological conditions. When cardiomyocytes are treated with $\mathrm{CoCL}_{2}$ to induce a hypoxic reaction, p53 levels increase concomitantly with a decrease in CHIP expression. However, if CHIP is ectopically expressed in cells before a hypoxic insult is given, p53 levels drop and cellular apoptosis is inhibited [106]. Similarly, promoting CHIP function using a HSP90 inhibitor (17-AAG) also prevents p53 accumulation and apoptosis in cardiomyocytes both in vivo and in vitro [106], suggesting that CHIP may offer a therapeutic target for p53-mediated apoptosis associated cardiac conditions that induce hypoxic stress. The in vivo significance of CHIP-mediated ubiquitination of cardiac p53 is illustrated in the case of myocardial infarction. Following myocardial infarction, p53 accumulates, inducing apoptosis and lending to the progression of heart failure. This increased expression of p53 is caused in part by a HIF-1a-dependent decrease in CHIP expression [106]. Transgenic mice that overexpress cardiac CHIP do not exhibit the same increase in p53 and, subsequently, don't suffer from the same degree of cardiomyocyte apoptosis and subsequent heart failure. These studies suggest that the decreased CHIP that occurs in the heart in myocardial infarction is one mechanism by which p53 is allowed to accumulate and induce cardiomyocyte apoptosis.

\section{A potential role for ubiquitin-mediated regulation of cardiac p53 in models of diabetes}

Although there are no reports of a link between ubiquitin-mediated regulation of p53 in the diabetic heart, there is evidence to suggest that such a mechanism may exist. Hyperglycemia activates p53 in cardiomyocytes to induce apoptosis [107]. Likewise, ventricular myocytes 
exposed to high glucose levels, mimicking diabetic hyperglycemia, exhibit increased p53 phosphorylation and myocyte cell death [108]. Given the fact that CHIP expression is also increased when cardiomyocytes are challenged with high glucose [109], the possibility exists that CHIP may play a role in regulating p53-related apoptosis in the diabetic heart, although additional studies will be needed to clarify whether this relationship exists, or perhaps could be used as a potential therapeutic mechanism for decreasing cardiac dysfunction associated with diabetes.

\section{Estrogen receptor signaling pathway}

\section{Estrogen receptor signaling in the heart}

Estrogen exerts a wide variety of effects on the cardiovascular system, including effects on vascular function, inflammatory responses, cardiac myocyte and stem cell survival, insulin sensitivity and metabolism and the development of hypertrophy. These effects of estrogen are mediated through the activation of estrogen receptors (ER). The estrogen receptor (ER) $\alpha$ and ER $\beta$ are ligand-activated receptors belonging to the nuclear receptor superfamily that mediate their physiological functions under the control of estrogen. ER $\alpha$ and ER $\beta$ exhibit tissue-specific expression in different species [110], and can regulate each other's activity in the same tissue [111]. In the mouse aorta, ER $\alpha$ predominantly upregulates target gene activity whereas ER $\beta$ tends towards inhibitory actions [111]. In contrast, in the mouse heart, ER $\beta$ stimulates more target genes than it inhibits, proving the vast array and tissue and cell specific nature of the ERs.

Estrogen receptor-mediated effects in the heart are vast. Estrogen can influence the level and activity of ion channels thereby playing an important role in repolarization of the heart, cardiac arrhythmias and cardiac contractility [112]. In the cardiac vasculature, estrogen promotes vascular recovery following injury and reduces atherosclerosis [113, 114]. Estrogen is also protective in other cardiac conditions such as I/R injury, cardiac hypertrophy, and myocardial infarction [115].

\section{The ubiquitin proteasome system regulates estrogen receptor stability}

The activation of nuclear receptors is coupled with their degradation via the UPS pathway [116-118]. Without ligand, ERs have a half-life of $\sim 4-5 \mathrm{~h}$ and undergo constant degradation [119]. However, even when bound with a ligand, the turnover of ligand-bound ER is dependent upon the specific ligand to which it is bound. For instance, increasing $17 \beta-$ estradiol, heat shock protein (Hsp)90 inhibitors, ATP depletion, and aryl hydrocarbon agonists all enhance (increase) degradation of the ER [120-123]. In contrast, the partial agonist/antagonist 4-hydoxytamoxifen (4-OHT), thyroid hormone, and protein kinase K activators inhibit receptor degradation, thereby increasing ER protein levels [124-126].

The UPS mediated-degradation of ER $\alpha$ occurs by at least 2 different mechanisms, depending on the presence or absence of ligand. In the presence of ligands, nuclear receptors do not remain permanently bound to a promoter, but instead undergo cycles of binding and unbinding [127-129]. This cycling of ligand-bound ER $\alpha$ requires proteasomal activity [130]. In the absence of estrogen, ER $\alpha$ is also ubiquitinated and degraded via the UPS pathway via a process that is regulated by a chaperone complex containing CHIP, a protein with both ubiquitin ligase and co-chaperone activities [131-133]. In cells lacking CHIP, degradation of unliganded ER $\alpha$ does not occur, suggesting a primary role for CHIP in the turnover of unbound ER $\alpha$ [134]. However, in the presence of estrogen, degradation of ER $\alpha$ occurs to the same extent in CHIP -/- and CHIP +/+ cells, suggesting that whereas CHIP is involved in the general protein quality control of $\mathrm{ER} \alpha$, an as yet undetermined ubiquitin ligase(s) is responsible for the ligand-mediated degradation of ER $\alpha$ [134]. Additional studies have shown that the estrogen-dependent ubiquitination of $\mathrm{ER} \alpha$ requires the $\mathrm{AD}$ core region within 
the ligand binding domain of $E R \alpha$, whereas ubiquitination of the receptor in the absence of ligand does not [134].

\section{Estrogen receptor signaling in cardiac diseases: could ubiquitin regulation be involved?}

In the last couple of years, the evidence demonstrating an involvement of ER signaling in various cardiovascular conditions has grown immensely. However, unlike the other signaling pathways discussed in this review, a role for ubiquitin-mediated regulation of this ER signaling has not been reported. Nevertheless, we believe that inclusion of a brief discussion of ER signaling in cardiac disease is worthwhile in the context of this review, as it highlights a burgeoning area of research in which ubiquitin-mediated signal modulation may prove to be important.

\section{ER signaling in cardiac hypertrophy}

Cardiac ER $\alpha$ and ER $\beta$ are up-regulated in human aortic stenosis [135]. In response to hypertension or aortic stenosis-mediated pressure overload, human male hearts exhibit left ventricular (LV) dilatation or eccentric hypertrophy, whereas female hearts maintain normal chamber size but develop increased wall thickness, consistent with concentric hypertrophy [136]. Estrogen exerts beneficial effects on cardiac remodeling by reversing pressure overload-induced LV dilatation and systolic dysfunction, and prevents decreased cardiac contractility following TAC hypertrophy [137, 138] [139]. The beneficial effects of $17 \beta-$ estradiol replacement on LV and myocyte hypertrophy is associated with a reduction in the TAC-induced increase in calcineurin protein levels and activity [139]. ER $\beta$ specifically modulates the cardioprotective effects of $\mathrm{E} 2$ in pressure overload induced cardiac hypertrophy [140-142]. Moreover, recent studies have identified that the ER $\beta$ axis is differentially regulated in pressure overload induced hypertrophy by regulating inflammatory pathways, mitochondrial bioenergetics, and oxidative stress-related pathways [143]. These mechanisms may explain the beneficial effects of E2 on cardiac hypertrophy.

\section{ER signaling in ischemia reperfusion injury}

Recent studies have elegantly demonstrated a role of estrogen and the activation of ER $\alpha$ and ER $\beta$ in the cardioprotection against experimentally-induced I/R injury seen in females (see recent comprehensive review by Deschamps, et al., 2010 [144]). These are fascinating findings given the lower incidence of cardiovascular disease that is seen in pre-menopausal human females [145-147]. Both acute and chronic ER $\alpha$ agonist treatment has been reported to be cardioprotective in I/R injury, regardless of whether treatment is given before or after the onset of the I/R insult [148] [149, 150], whereas genetic deletion of functional ER $\alpha$ results in increased susceptibility to I/R injury [151]. Furthermore, E2 administered to ER $\alpha$ $-/-$ mice challenged with MI decreases infarct sizes [152], an effect not seen in ER $\beta-/-$ animals [152]. ER $\beta-/-$ mice display a consistently enhanced injury in response to I/R, suggesting a significant cardioprotective role for ER $\beta$ [152-155]. A number of mechanisms have been attributed to estrogen-mediated cardioprotection, including NO, and PI2K/AKT (see recent comprehensive review by Deschamps, et al., 2010 [144]). Recent studies have also found that estrogen prevents cardiomyocyte apoptosis by suppressing $\mathrm{p} 38$-mediated activation of p53 [156].

\section{Summary}

The process that cells go through to recognize extracellular signaling molecules to stimulate an intracellular response occurs in a highly complex and diverse manner in most cells, including the cardiomyocyte. The majority of the attention given to these signaling pathways has previously focused on processes that enhance signaling, mainly by protein kinases. However, multiple post-translational modifications, including ubiquitination, have recently 
been recognized that regulate signaling in both inhibitory and stimulatory ways. In this review, we have presented some of the recent studies that have identified how the UPS, directed by its substrate-specific ubiquitin ligases, regulates signaling mediated by MAPK/ JNK, calcineurin, FOXO, p53, and the estrogen receptors $\alpha$ and $\beta$. We highlight the roles that these signaling pathways play in common cardiac diseases, and how these roles can be modulated and regulated by the influence of members of the UPS. Together, the studies presented in this review, highlight the emerging importance of the UPS in cardiac signal transduction, particularly in pathways significant to cardiac health and disease.

\section{Highlights}

$>\quad$ The ubiquitin proteasome system (UPS) regulates signal transduction in the heart

$>\quad$ The UPS regulates JNK, calcineurin, FOXO, p53, and estrogen receptor signaling in relevant models of cardiac disease

$>\quad$ Regulation of the UPS can influence outcomes in cardiac hypertrophy, heart failure, ischemia, and diabetic cardiomyopathy

$>\quad$ The UPS affects cardiac signal transduction pathways significant to cardiac health and disease.

\section{Non-standard abbreviations}

AF1/2

AP-1

AKT

ARF-BP1

ATM

CARP 1/2

CBP

CHIP

COP1

DBD

DCM

E1

E2

E3

E6-AP

ER $\alpha / \beta$

Fbw7

FOXO

GSK3ß

HAUSP activation function $1 / 2$ domains

activator protein 1

protein kinase $\mathrm{B}$

ARF binding protein 1

ataxia telangiectasia mutated

caspase associated ring protein $1 / 2$

CREB binding protein

C-terminus of HSC70-Interacting Protein

constitutively photomorphogenic 1 (ubiquitin ligase)

DNA binding domain

dilated cardiomyopathy

ubiquitin activating enzyme

ubiquitin conjugating enzyme

ubiquitin ligase enzymes

E6-associated protein

estrogen receptor alpha/beta

F-box and WD repeat domain-containing 7

forkhead box

glycogen synthase kinase- $3 \beta$ isoform

herpesvirus-associated ubiquitin-specific protease 


\begin{tabular}{|c|c|}
\hline HSP & heat shock protein \\
\hline $\mathbf{I} / \mathbf{R}$ & ischemia reperfusion \\
\hline JNK & c-Jun N-terminal kinase \\
\hline SUMO & small ubiquitin-like modifier \\
\hline LBD & ligand binding domain \\
\hline МАPK & mitogen activated protein kinase \\
\hline $\begin{array}{l}\text { MAFbx (aka } \\
\text { atrogin-1) }\end{array}$ & muscle atrophy F-box \\
\hline MDM2 & murine double minute 2 \\
\hline MEKK1 & mitogen-activated protein kinase kinase kinase \\
\hline MKP-1 & MAPK phosphatase 1 \\
\hline MI & myocardial infarction \\
\hline MuRF1 & muscle ring finger- 1 \\
\hline NFAT & nuclear factor of activated T cells \\
\hline p53 & tumor protein 53 \\
\hline TOPORS & $\begin{array}{l}\text { topoisomerase I binding, arginine/serine-rich, E3 ubiquitin } \\
\text { protein ligase }\end{array}$ \\
\hline TIGAR & TP53-induced glycolysis and apoptosis regulator \\
\hline TAC & trans-aortic constriction \\
\hline UBC9 & ubiquitin-like protein 9 \\
\hline USP & ubiquitin specific protease \\
\hline UPS & ubiquitin proteasome system \\
\hline
\end{tabular}

\section{Acknowledgments}

The authors' laboratories are supported by the National Institutes of Health (R37HL065619 to C.P., R01HL104129 to M.W.)

\section{References}

1. Raiborg C, Stenmark H. The ESCRT machinery in endosomal sorting of ubiquitylated membrane proteins. Nature. 2009; 458:445-452. [PubMed: 19325624]

2. Bhoj VG, Chen ZJ. Ubiquitylation in innate and adaptive immunity. Nature. 2009; 458:430-437. [PubMed: 19325622]

3. Hofmann RM, Pickart CM. In vitro assembly and recognition of Lys-63 polyubiquitin chains. J Biol Chem. 2001; 276:27936-27943. [PubMed: 11369780]

4. Hoeller D, Dikic I. Targeting the ubiquitin system in cancer therapy. Nature. 2009; 458:438-444. [PubMed: 19325623]

5. Greenwood DD. Critical bandwidth and consonance in relation to cochlear frequency-position coordinates. Hear Res. 1991; 54:164-208. [PubMed: 1938625]

6. Heemers HV, Tindall DJ. Unraveling the complexities of androgen receptor signaling in prostate cancer cells. Cancer Cell. 2009; 15:245-247. [PubMed: 19345321]

7. Ikeda F, Dikic I. Atypical ubiquitin chains: new molecular signals 'Protein Modifications: Beyond the Usual Suspects' review series. EMBO Rep. 2008; 9:536-542. [PubMed: 18516089] 
8. Hicke L. Protein regulation by monoubiquitin. Nat Rev Mol Cell Biol. 2001; 2:195-201. [PubMed: 11265249]

9. Trotman LC, Wang X, Alimonti A, Chen Z, Teruya-Feldstein J, Yang H, et al. Ubiquitination regulates PTEN nuclear import and tumor suppression. Cell. 2007; 128:141-156. [PubMed: 17218261]

10. Hicke L. Gettin' down with ubiquitin: turning off cell-surface receptors, transporters and channels. Trends Cell Biol. 1999; 9:107-112. [PubMed: 10201076]

11. Bogoyevitch MA, Gillespie-Brown J, Ketterman AJ, Fuller SJ, Ben-Levy R, Ashworth A, et al. Stimulation of the stress-activated mitogen-activated protein kinase subfamilies in perfused heart. p38/RK mitogen-activated protein kinases and c-Jun N-terminal kinases are activated by is chemia/reperfusion. Circ Res. 1996; 79:162-173. [PubMed: 8755992]

12. Petrich BG, Molkentin JD, Wang Y. Temporal activation of c-Jun N-terminal kinase in adult transgenic heart via cre-loxP-mediated DNA recombination. FASEB J. 2003; 17:749-751. [PubMed: 12594183]

13. Goldsmith ZG, Dhanasekaran DN. G protein regulation of MAPK networks. Oncogene. 2007; 26:3122-3142. [PubMed: 17496911]

14. Pandur P, Maurus D, Kuhl M. Increasingly complex: new players enter the Wnt signaling network. Bioessays. 2002; 24:881-884. [PubMed: 12325120]

15. Rose BA, Force T, Wang Y. Mitogen-activated protein kinase signaling in the heart: angels versus demons in a heart-breaking tale. Physiol Rev. 2010; 90:1507-15046. [PubMed: 20959622]

16. Pandur P, Lasche M, Eisenberg LM, Kuhl M. Wnt-11 activation of a non-canonical Wnt signalling pathway is required for cardiogenesis. Nature. 2002; 418:636-641. [PubMed: 12167861]

17. Zhou W, Lin L, Majumdar A, Li X, Zhang X, Liu W, et al. Modulation of morphogenesis by noncanonical Wnt signaling requires ATF/CREB family-mediated transcriptional activation of TGFbeta2. Nat Genet. 2007; 39:1225-1234. [PubMed: 17767158]

18. Sugden PH, Clerk A. "Stress-responsive" mitogen-activated protein kinases (c-Jun N-terminal kinases and p38 mitogen-activated protein kinases) in the myocardium. Circ Res. 1998; 83:345352. [PubMed: 9721691]

19. Yin T, Sandhu G, Wolfgang CD, Burrier A, Webb RL, Rigel DF, et al. Tissue-specific pattern of stress kinase activation in ischemic/reperfused heart and kidney. J Biol Chem. 1997; 272:1994319950. [PubMed: 9242662]

20. Hreniuk D, Garay M, Gaarde W, Monia BP, McKay RA, Cioffi CL. Inhibition of c-Jun N-terminal kinase 1, but not c-Jun N-terminal kinase 2, suppresses apoptosis induced by ischemia/ reoxygenation in rat cardiac myocytes. Mol Pharmacol. 2001; 59:867-874. [PubMed: 11259632]

21. Knight RJ, Buxton DB. Stimulation of c-Jun kinase and mitogen-activated protein kinase by ischemia and reperfusion in the perfused rat heart. Biochem Biophys Res Commun. 1996; 218:8388. [PubMed: 8573181]

22. Laderoute KR, Webster KA. Hypoxia/reoxygenation stimulates Jun kinase activity through redox signaling in cardiac myocytes. Circ Res. 1997; 80:336-344. [PubMed: 9048653]

23. Clerk A, Fuller SJ, Michael A, Sugden PH. Stimulation of "stress-regulated" mitogen-activated protein kinases (stress-activated protein kinases/c-Jun N-terminal kinases and p38-mitogenactivated protein kinases) in perfused rat hearts by oxidative and other stresses. J Biol Chem. 1998; 273:7228-7234. [PubMed: 9516415]

24. Laine A, Ronai Z. Ubiquitin chains in the ladder of MAPK signaling. Sci STKE. 2005 2005:re5.

25. Li HH, Du J, Fan YN, Zhang ML, Liu DP, Li L, et al. The Ubiquitin Ligase MuRF1 Protects Against Cardiac Ischemia/Reperfusion Injury by Its Proteasome-Dependent Degradation of Phospho-c-Jun. Am J Pathol. 2011; 178:1043-1058. [PubMed: 21356357]

26. Xie P, Guo S, Fan Y, Zhang H, Gu D, Li H. Atrogin-1/MAFbx enhances simulated ischemia/ reperfusion-induced apoptosis in cardiomyocytes through degradation of MAPK phosphatase-1 and sustained JNK activation. J Biol Chem. 2009; 284:5488-5496. [PubMed: 19117950]

27. Guo B, Yang SH, Witty J, Sharrocks AD. Signalling pathways and the regulation of SUMO modification. Biochemical Society transactions. 2007; 35:1414-1418. [PubMed: 18031234]

28. Yang SH, Sharrocks AD. Convergence of the SUMO and MAPK pathways on the ETS-domain transcription factor Elk-1. Biochemical Society symposium. 2006:121-129. [PubMed: 16626293] 
29. Xia Y, Wang J, Xu S, Johnson GL, Hunter T, Lu Z. MEKK1 mediates the ubiquitination and degradation of c-Jun in response to osmotic stress. Mol Cell Biol. 2007; 27:510-517. [PubMed: 17101801]

30. Lu Z, Xu S, Joazeiro C, Cobb MH, Hunter T. The PHD domain of MEKK1 acts as an E3 ubiquitin ligase and mediates ubiquitination and degradation of ERK1/2. Mol Cell. 2002; 9:945-956. [PubMed: 12049732]

31. Nateri AS, Riera-Sans L, Da Costa C, Behrens A. The ubiquitin ligase SCFFbw7 antagonizes apoptotic JNK signaling. Science. 2004; 303:1374-1378. [PubMed: 14739463]

32. Wertz IE, O'Rourke KM, Zhang Z, Dornan D, Arnott D, Deshaies RJ, et al. Human De-etiolated-1 regulates c-Jun by assembling a CUL4A ubiquitin ligase. Science. 2004; 303:1371-1374. [PubMed: 14739464]

33. Gao M, Labuda T, Xia Y, Gallagher E, Fang D, Liu YC, et al. Jun turnover is controlled through JNK-dependent phosphorylation of the E3 ligase Itch. Science. 2004; 306:271-275. [PubMed: 15358865]

34. Dickens M, Rogers JS, Cavanagh J, Raitano A, Xia Z, Halpern JR, et al. A cytoplasmic inhibitor of the JNK signal transduction pathway. Science. 1997; 277:693-696. [PubMed: 9235893]

35. Whitmarsh AJ, Cavanagh J, Tournier C, Yasuda J, Davis RJ. A mammalian scaffold complex that selectively mediates MAP kinase activation. Science. 1998; 281:1671-1674. [PubMed: 9733513]

36. Wei N, Deng XW. Making sense of the COP9 signalosome. A regulatory protein complex conserved from Arabidopsis to human. Trends in genetics : TIG. 1999; 15:98-103. [PubMed: 10203806]

37. Fang D, Elly C, Gao B, Fang N, Altman Y, Joazeiro C, et al. Dysregulation of T lymphocyte function in itchy mice: a role for Itch in TH2 differentiation. Nature immunology. 2002; 3:281287. [PubMed: 11828324]

38. Perry WL, Hustad CM, Swing DA, O'Sullivan TN, Jenkins NA, Copeland NG. The itchy locus encodes a novel ubiquitin protein ligase that is disrupted in a18H mice. Nat Genet. 1998; 18:143146. [PubMed: 9462742]

39. Dong C, Yang DD, Wysk M, Whitmarsh AJ, Davis RJ, Flavell RA. Defective T cell differentiation in the absence of Jnk1. Science. 1998; 282:2092-2095. [PubMed: 9851932]

40. Dong C, Yang DD, Tournier C, Whitmarsh AJ, Xu J, Davis RJ, et al. JNK is required for effector T-cell function but not for T-cell activation. Nature. 2000; 405:91-94. [PubMed: 10811224]

41. Wang J. Cardiac function and disease: emerging role of small ubiquitin-related modifier. Wiley interdisciplinary reviews Systems biology and medicine. 2011; 3:446-457. [PubMed: 21197655]

42. Muller S, Berger M, Lehembre F, Seeler JS, Haupt Y, Dejean A. c-Jun and p53 activity is modulated by SUMO-1 modification. J Biol Chem. 2000; 275:13321-13329. [PubMed: 10788439]

43. Klee CB, Crouch TH, Krinks MH. Calcineurin: a calcium- and calmodulin-binding protein of the nervous system. Proc Natl Acad Sci U S A. 1979; 76:6270-6273. [PubMed: 293720]

44. Okamura H, Aramburu J, Garcia-Rodriguez C, Viola JP, Raghavan A, Tahiliani M, et al. Concerted dephosphorylation of the transcription factor NFAT1 induces a conformational switch that regulates transcriptional activity. Mol Cell. 2000; 6:539-550. [PubMed: 11030334]

45. Suzuki E, Nishimatsu H, Satonaka H, Walsh K, Goto A, Omata M, et al. Angiotensin II induces myocyte enhancer factor 2- and calcineurin/nuclear factor of activated $\mathrm{T}$ cell-dependent transcriptional activation in vascular myocytes. Circ Res. 2002; 90:1004-1011. [PubMed: 12016267]

46. Molkentin JD, Lu JR, Antos CL, Markham B, Richardson J, Robbins J, et al. A calcineurindependent transcriptional pathway for cardiac hypertrophy. Cell. 1998; 93:215-228. [PubMed: 9568714]

47. Chin ER, Olson EN, Richardson JA, Yang Q, Humphries C, Shelton JM, et al. A calcineurindependent transcriptional pathway controls skeletal muscle fiber type. Genes Dev. 1998; 12:2499_ 2509. [PubMed: 9716403]

48. Gwack Y, Sharma S, Nardone J, Tanasa B, Iuga A, Srikanth S, et al. A genome-wide Drosophila RNAi screen identifies DYRK-family kinases as regulators of NFAT. Nature. 2006; 441:646-650. [PubMed: 16511445] 
49. Okamura H, Garcia-Rodriguez C, Martinson H, Qin J, Virshup DM, Rao A. A conserved docking motif for CK1 binding controls the nuclear localization of NFAT1. Mol Cell Biol. 2004; 24:41844195. [PubMed: 15121840]

50. Fan Y, Xie P, Zhang T, Zhang H, Gu D, She M, et al. Regulation of the stability and transcriptional activity of NFATc4 by ubiquitination. FEBS Lett. 2008; 582:4008-4014. [PubMed: 19026640]

51. Ni YG, Wang N, Cao DJ, Sachan N, Morris DJ, Gerard RD, et al. FoxO transcription factors activate Akt and attenuate insulin signaling in heart by inhibiting protein phosphatases. Proc Natl Acad Sci U S A. 2007; 104:20517-20522. [PubMed: 18077353]

52. Li HH, Willis MS, Lockyer P, Miller N, McDonough H, Glass DJ, et al. Atrogin-1 inhibits Aktdependent cardiac hypertrophy in mice via ubiquitin-dependent coactivation of Forkhead proteins. J Clin Invest. 2007; 117:3211-3223. [PubMed: 17965779]

53. Li HH, Kedar V, Zhang C, McDonough H, Arya R, Wang DZ, et al. Atrogin-1/muscle atrophy Fbox inhibits calcineurin-dependent cardiac hypertrophy by participating in an SCF ubiquitin ligase complex. J Clin Invest. 2004; 114:1058-1071. [PubMed: 15489953]

54. Tang M, Li J, Huang W, Su H, Liang Q, Tian Z, et al. Proteasome functional insufficiency activates the calcineurin-NFAT pathway in cardiomyocytes and promotes maladaptive remodelling of stressed mouse hearts. Cardiovasc Res. 2010; 88:424-433. [PubMed: 20601385]

55. Li F, Wang X, Yi XP, Gerdes AM. Structural basis of ventricular remodeling: role of the myocyte. Current heart failure reports. 2004; 1:5-8. [PubMed: 16036018]

56. Liu J, Tang M, Mestril R, Wang X. Aberrant protein aggregation is essential for a mutant desmin to impair the proteolytic function of the ubiquitin-proteasome system in cardiomyocytes. $\mathrm{J}$ Mol Cell Cardiol. 2006; 40:451-454. [PubMed: 16481005]

57. Liu J, Chen Q, Huang W, Horak KM, Zheng H, Mestril R, et al. Impairment of the ubiquitinproteasome system in desminopathy mouse hearts. FASEB J. 2006; 20:362-364. [PubMed: 16371426]

58. Papanicolaou KN, Izumiya Y, Walsh K. Forkhead transcription factors and cardiovascular biology. Circ Res. 2008; 102:16-31. [PubMed: 18174472]

59. Maiese K, Hou J, Chong ZZ, Shang YC. A fork in the path: Developing therapeutic inroads with FoxO proteins. Oxidative medicine and cellular longevity. 2009; 2:119-129. [PubMed: 20592766]

60. Ronnebaum SM, Patterson C. The FoxO family in cardiac function and dysfunction. Annu Rev Physiol. 2010; 72:81-94. [PubMed: 20148668]

61. Tremblay ML, Giguere V. Phosphatases at the heart of FoxO metabolic control. Cell Metab. 2008; 7:101-103. [PubMed: 18249169]

62. Colao A. The GH-IGF-I axis and the cardiovascular system: clinical implications. Clinical endocrinology. 2008; 69:347-358. [PubMed: 18462260]

63. Alessi DR, James SR, Downes CP, Holmes AB, Gaffney PR, Reese CB, et al. Characterization of a 3-phosphoinositide-dependent protein kinase which phosphorylates and activates protein kinase Balpha. Curr Biol. 1997; 7:261-269. [PubMed: 9094314]

64. Sarbassov DD, Guertin DA, Ali SM, Sabatini DM. Phosphorylation and regulation of Akt/PKB by the rictor-mTOR complex. Science. 2005; 307:1098-1101. [PubMed: 15718470]

65. Meier R, Alessi DR, Cron P, Andjelkovic M, Hemmings BA. Mitogenic activation, phosphorylation, and nuclear translocation of protein kinase Bbeta. J Biol Chem. 1997; 272:30491-30497. [PubMed: 9374542]

66. Brownawell AM, Kops GJ, Macara IG, Burgering BM. Inhibition of nuclear import by protein kinase $\mathrm{B}$ (Akt) regulates the subcellular distribution and activity of the forkhead transcription factor AFX. Mol Cell Biol. 2001; 21:3534-3546. [PubMed: 11313479]

67. Biggs WH 3rd, Meisenhelder J, Hunter T, Cavenee WK, Arden KC. Protein kinase B/Aktmediated phosphorylation promotes nuclear exclusion of the winged helix transcription factor FKHR1. Proc Natl Acad Sci U S A. 1999; 96:7421-7426. [PubMed: 10377430]

68. Brunet A, Kanai F, Stehn J, Xu J, Sarbassova D, Frangioni JV, et al. 14-3-3 transits to the nucleus and participates in dynamic nucleocytoplasmic transport. J Cell Biol. 2002; 156:817-828. [PubMed: 11864996]

69. Plas DR, Thompson CB. Akt activation promotes degradation of tuberin and FOXO3a via the proteasome. J Biol Chem. 2003; 278:12361-12366. [PubMed: 12517744] 
70. Huang H, Regan KM, Wang F, Wang D, Smith DI, van Deursen JM, et al. Skp2 inhibits FOXO1 in tumor suppression through ubiquitin-mediated degradation. Proc Natl Acad Sci U S A. 2005; 102:1649-1654. [PubMed: 15668399]

71. Li F, Xie P, Fan Y, Zhang H, Zheng L, Gu D, et al. C terminus of Hsc70-interacting protein promotes smooth muscle cell proliferation and survival through ubiquitin-mediated degradation of FoxO1. J Biol Chem. 2009; 284:20090-20098. [PubMed: 19483080]

72. Yang JY, Zong CS, Xia W, Yamaguchi H, Ding Q, Xie X, et al. ERK promotes tumorigenesis by inhibiting FOXO3a via MDM2-mediated degradation. Nat Cell Biol. 2008; 10:138-148. [PubMed: 18204439]

73. Hu MC, Lee DF, Xia W, Golfman LS, Ou-Yang F, Yang JY, et al. IkappaB kinase promotes tumorigenesis through inhibition of forkhead FOXO3a. Cell. 2004; 117:225-237. [PubMed: 15084260]

74. Kato S, Ding J, Pisck E, Jhala US, Du K. COP1 functions as a FoxO1 ubiquitin E3 ligase to regulate FoxO1-mediated gene expression. J Biol Chem. 2008; 283:35464-35473. [PubMed: 18815134]

75. Brenkman AB, de Keizer PL, van den Broek NJ, Jochemsen AG, Burgering BM. Mdm2 induces mono-ubiquitination of FOXO4. PLoS ONE. 2008; 3 e2819.

76. van der Horst A, de Vries-Smits AM, Brenkman AB, van Triest MH, van den Broek N, Colland F, et al. FOXO4 transcriptional activity is regulated by monoubiquitination and USP7/HAUSP. Nat Cell Biol. 2006; 8:1064-1073. [PubMed: 16964248]

77. Morris JB, Kenney B, Huynh H, Woodcock EA. Regulation of the proapoptotic factor FOXO1 (FKHR) in cardiomyocytes by growth factors and alpha1-adrenergic agonists. Endocrinology. 2005; 146:4370-4376. [PubMed: 16020479]

78. Yue TL, Bao W, Gu JL, Cui J, Tao L, Ma XL, et al. Rosiglitazone treatment in Zucker diabetic Fatty rats is associated with ameliorated cardiac insulin resistance and protection from ischemia/ reperfusion-induced myocardial injury. Diabetes. 2005; 54:554-562. [PubMed: 15677515]

79. Chen Y, Park S, Li Y, Missov E, Hou M, Han X, et al. Alterations of gene expression in failing myocardium following left ventricular assist device support. Physiol Genomics. 2003; 14:251260. [PubMed: 12824457]

80. Hannenhalli S, Putt ME, Gilmore JM, Wang J, Parmacek MS, Epstein JA, et al. Transcriptional genomics associates FOX transcription factors with human heart failure. Circulation. 2006; 114:1269-1276. [PubMed: 16952980]

81. Philip-Couderc P, Tavares NI, Roatti A, Lerch R, Montessuit C, Baertschi AJ. Forkhead transcription factors coordinate expression of myocardial KATP channel subunits and energy metabolism. Circ Res. 2008; 102:e20-e35. [PubMed: 18202312]

82. Sengupta A, Molkentin JD, Paik JH, DePinho RA, Yutzey KE. FoxO transcription factors promote cardiomyocyte survival upon induction of oxidative stress. J Biol Chem. 2011; 286:7468-7478. [PubMed: 21159781]

83. Pikkarainen S, Kennedy RA, Marshall AK, Tham el L, Lay K, Kriz TA, et al. Regulation of expression of the rat orthologue of mouse double minute 2 (MDM2) by $\mathrm{H}(2) \mathrm{O}(2)$-induced oxidative stress in neonatal rat cardiac myocytes. J Biol Chem. 2009; 284:27195-27210. [PubMed: 19638633]

84. Zhang C, Xu Z, He XR, Michael LH, Patterson C. CHIP, a cochaperone/ubiquitin ligase that regulates protein quality control, is required for maximal cardioprotection after myocardial infarction in mice. Am J Physiol Heart Circ Physiol. 2005; 288:H2836-H2842. [PubMed: 15665051]

85. Kubbutat MH, Jones SN, Vousden KH. Regulation of p53 stability by Mdm2. Nature. 1997; 387:299-303. [PubMed: 9153396]

86. Honda R, Tanaka H, Yasuda H. Oncoprotein MDM2 is a ubiquitin ligase E3 for tumor suppressor p53. FEBS Lett. 1997; 420:25-27. [PubMed: 9450543]

87. Li M, Brooks CL, Wu-Baer F, Chen D, Baer R, Gu W. Mono- versus polyubiquitination: differential control of p53 fate by Mdm2. Science. 2003; 302:1972-1975. [PubMed: 14671306]

88. Lohrum MA, Woods DB, Ludwig RL, Balint E, Vousden KH. C-terminal ubiquitination of p53 contributes to nuclear export. Mol Cell Biol. 2001; 21:8521-8532. [PubMed: 11713287] 
89. Manfredi JJ. The Mdm2-p53 relationship evolves: Mdm2 swings both ways as an oncogene and a tumor suppressor. Genes Dev. 2010; 24:1580-1589. [PubMed: 20679392]

90. Rodriguez MS, Desterro JM, Lain S, Lane DP, Hay RT. Multiple C-terminal lysine residues target p53 for ubiquitin-proteasome-mediated degradation. Mol Cell Biol. 2000; 20:8458-67. [PubMed: 11046142]

91. Krummel KA, Lee CJ, Toledo F, Wahl GM. The C-terminal lysines fine-tune P53 stress responses in a mouse model but are not required for stability control or transactivation. Proc Natl Acad Sci U S A. 2005; 102:10188-10193. [PubMed: 16006521]

92. Feng L, Lin T, Uranishi H, Gu W, Xu Y. Functional analysis of the roles of posttranslational modifications at the p53 C terminus in regulating p53 stability and activity. Mol Cell Biol. 2005; 25:5389-5395. [PubMed: 15964796]

93. Chan WM, Mak MC, Fung TK, Lau A, Siu WY, Poon RY. Ubiquitination of p53 at multiple sites in the DNA-binding domain. Molecular cancer research : MCR. 2006; 4:15-25. [PubMed: 16446403]

94. Li M, Chen D, Shiloh A, Luo J, Nikolaev AY, Qin J, et al. Deubiquitination of p53 by HAUSP is an important pathway for p53 stabilization. Nature. 2002; 416:648-653. [PubMed: 11923872]

95. Ringshausen I, O’Shea CC, Finch AJ, Swigart LB, Evan GI. Mdm2 is critically and continuously required to suppress lethal p53 activity in vivo. Cancer Cell. 2006; 10:501-514. [PubMed: 17157790]

96. McDonough H, Patterson C. CHIP: a link between the chaperone and proteasome systems. Cell tress Chaperones. 2003; 8:303-308.

97. Weger S, Hammer E, Heilbronn R. Topors acts as a SUMO-1 E3 ligase for p53 in vitro and in vivo. EBS Lett. 2005; 579:5007-5012.

98. Rajendra R, Malegaonkar D, Pungaliya P, Marshall H, Rasheed Z, Brownell J, et al. Topors unctions as an E3 ubiquitin ligase with specific E2 enzymes and ubiquitinates p53. J Biol Chem. 2004; 279:36440-36444. [PubMed: 15247280]

99. Yang W, Rozan LM, McDonald ER 3rd, Navaraj A, Liu JJ, Matthew EM, et al. CARPs are ubiquitin ligases that promote MDM2-independent p53 and phospho-p53ser20 degradation. J Biol Chem. 2007; 282:3273-3281. [PubMed: 17121812]

100. Chen D, Kon N, Li M, Zhang W, Qin J, Gu W. ARF-BP1/Mule is a critical mediator of the ARF tumor suppressor. Cell. 2005; 121:1071-1083. [PubMed: 15989956]

101. Grossman SR, Deato ME, Brignone C, Chan HM, Kung AL, Tagami H, et al. Polyubiquitination of p53 by a ubiquitin ligase activity of p300. Science. 2003; 300:342-344. [PubMed: 12690203]

102. Yamasaki S, Yagishita N, Sasaki T, Nakazawa M, Kato Y, Yamadera T, et al. Cytoplasmic destruction of p53 by the endoplasmic reticulum-resident ubiquitin ligase 'Synoviolin'. EMBO J. 2007; 26:113-122. [PubMed: 17170702]

103. Chatterjee A, Mir SA, Dutta D, Mitra A, Pathak K, Sarkar S. Analysis of p53 and NF-kappaB signaling in modulating the cardiomyocyte fate during hypertrophy. J Cell Physiol. 2010

104. Sano M, Minamino T, Toko H, Miyauchi H, Orimo M, Qin Y, et al. p53-induced inhibition of Hif-1 causes cardiac dysfunction during pressure overload. Nature. 2007; 446:444-448. [PubMed: 17334357]

105. Birks EJ, Latif N, Enesa K, Folkvang T, Luong le A, Sarathchandra P, et al. Elevated p53 expression is associated with dysregulation of the ubiquitin-proteasome system in dilated cardiomyopathy. Cardiovasc Res. 2008; 79:472-480. [PubMed: 18375498]

106. Naito AT, Okada S, Minamino T, Iwanaga K, Liu ML, Sumida T, et al. Promotion of CHIPmediated p53 degradation protects the heart from ischemic injury. Circ Res. 2010; 106:16921702. [PubMed: 20413784]

107. Yu XY, Geng YJ, Liang JL, Lin QX, Lin SG, Zhang S, et al. High levels of glucose induce apoptosis in cardiomyocyte via epigenetic regulation of the insulin-like growth factor receptor. Exp Cell Res. 2010; 316:2903-2909. [PubMed: 20633551]

108. Fiordaliso F, Leri A, Cesselli D, Limana F, Safai B, Nadal-Ginard B, et al. Hyperglycemia activates p53 and p53-regulated genes leading to myocyte cell death. Diabetes. 2001; 50:23632375. [PubMed: 11574421] 
109. Kobayashi S, Mao K, Zheng H, Wang X, Patterson C, O'Connell TD, et al. Diminished GATA4 protein levels contribute to hyperglycemia-induced cardiomyocyte injury. J Biol Chem. 2007; 282:21945-21952. [PubMed: 17525155]

110. Couse JF, Lindzey J, Grandien K, Gustafsson JA, Korach KS. Tissue distribution and quantitative analysis of estrogen receptor-alpha (ERalpha) and estrogen receptor-beta (ERbeta) messenger ribonucleic acid in the wild-type and ERalpha-knockout mouse. Endocrinology. 1997; 138:46134621. [PubMed: 9348186]

111. Lindberg MK, Moverare S, Skrtic S, Gao H, Dahlman-Wright K, Gustafsson JA, et al. Estrogen receptor (ER)-beta reduces ERalpha-regulated gene transcription, supporting a "ying yang" relationship between ERalpha and ERbeta in mice. Mol Endocrinol. 2003; 17:203-208. [PubMed: 12554748]

112. Saito T, Ciobotaru A, Bopassa JC, Toro L, Stefani E, Eghbali M. Estrogen contributes to gender differences in mouse ventricular repolarization. Circ Res. 2009; 105:343-352. [PubMed: 19608983]

113. Meyer MR, Barton M. ERalpha, ERbeta, and gpER: novel aspects of oestrogen receptor signalling in atherosclerosis. Cardiovasc Res. 2009; 83:605-610. [PubMed: 19541668]

114. Adams MR, Kaplan JR, Manuck SB, Koritnik DR, Parks JS, Wolfe MS, et al. Inhibition of coronary artery atherosclerosis by 17-beta estradiol in ovariectomized monkeys. Lack of an effect of added progesterone. Arteriosclerosis. 1990; 10:1051-1057. [PubMed: 2244855]

115. Murphy E. Estrogen signaling and cardiovascular disease. Circ Res. 2011; 109:687-696. [PubMed: 21885836]

116. Blanquart C, Barbier O, Fruchart JC, Staels B, Glineur C. Peroxisome proliferator-activated receptor alpha (PPARalpha ) turnover by the ubiquitin-proteasome system controls the ligandinduced expression level of its target genes. J Biol Chem. 2002; 277:37254-37259. [PubMed: 12118000]

117. Dace A, Zhao L, Park KS, Furuno T, Takamura N, Nakanishi M, et al. Hormone binding induces rapid proteasome-mediated degradation of thyroid hormone receptors. Proc Natl Acad Sci U S A. 2000; 97:8985-8990. [PubMed: 10908671]

118. Boudjelal M, Wang Z, Voorhees JJ, Fisher GJ. Ubiquitin/proteasome pathway regulates levels of retinoic acid receptor gamma and retinoid $\mathrm{X}$ receptor alpha in human keratinocytes. Cancer Res. 2000; 60:2247-2252. [PubMed: 10786691]

119. Eckert RL, Mullick A, Rorke EA, Katzenellenbogen BS. Estrogen receptor synthesis and turnover in MCF-7 breast cancer cells measured by a density shift technique. Endocrinology. 1984; 114:629-637. [PubMed: 6690295]

120. Alarid ET, Bakopoulos N, Solodin N. Proteasome-mediated proteolysis of estrogen receptor: a novel component in autologous down-regulation. Mol Endocrinol. 1999; 13:1522-1534. [PubMed: 10478843]

121. Devin-Leclerc J, Meng X, Delahaye F, Leclerc P, Baulieu EE, Catelli MG. Interaction and dissociation by ligands of estrogen receptor and Hsp90: the antiestrogen RU 58668 induces a protein synthesis-dependent clustering of the receptor in the cytoplasm. Mol Endocrinol. 1998; 12:842-854. [PubMed: 9626660]

122. Dauvois S, Danielian PS, White R, Parker MG. Antiestrogen ICI 164,384 reduces cellular estrogen receptor content by increasing its turnover. Proc Natl Acad Sci U S A. 1992; 89:40374041. [PubMed: 1570330]

123. Magro EM, Martinez JM. [Statistical trial of succinylcholine]. Revista espanola de anestesiologia y reanimacion. 1975; 22:1-35. [PubMed: 1144892]

124. Laios I, Journe F, Laurent G, Nonclercq D, Toillon RA, Seo HS, et al. Mechanisms governing the accumulation of estrogen receptor alpha in MCF-7 breast cancer cells treated with hydroxytamoxifen and related antiestrogens. J Steroid Biochem Mol Biol. 2003; 87:207-221. [PubMed: 14672741]

125. Alarid ET, Preisler-Mashek MT, Solodin NM. Thyroid hormone is an inhibitor of estrogeninduced degradation of estrogen receptor-alpha protein: estrogen-dependent proteolysis is not essential for receptor transactivation function in the pituitary. Endocrinology. 2003; 144:34693476. [PubMed: 12865327] 
126. Tsai KS, Yang RS, Liu SH. Benzo[a]pyrene regulates osteoblast proliferation through an estrogen receptor-related cyclooxygenase-2 pathway. Chem Res Toxicol. 2004; 17:679-684. [PubMed: 15144225]

127. Galigniana MD, Harrell JM, Housley PR, Patterson C, Fisher SK, Pratt WB. Retrograde transport of the glucocorticoid receptor in neurites requires dynamic assembly of complexes with the protein chaperone hsp90, is linked to the CHIP component of the machinery for proteasomal degradation. Brain Res Mol Brain Res. 2004; 123:27-36. [PubMed: 15046863]

127. Stenoien DL, Nye AC, Mancini MG, Patel K, Dutertre M, O’Malley BW, et al. Ligand-mediated assembly and real-time cellular dynamics of estrogen receptor alpha-coactivator complexes in living cells. Mol Cell Biol. 2001; 21:4404-4412. [PubMed: 11390668]

129. Shang Y, Hu X, DiRenzo J, Lazar MA, Brown M. Cofactor dynamics and sufficiency in estrogen receptor-regulated transcription. Cell. 2000; 103:843-852. [PubMed: 11136970]

130. Reid G, Hubner MR, Metivier R, Brand H, Denger S, Manu D, et al. Cyclic, proteasomemediated turnover of unliganded and liganded ERalpha on responsive promoters is an integral feature of estrogen signaling. Mol Cell. 2003; 11:695-707. [PubMed: 12667452]

131. Fan M, Park A, Nephew KP. CHIP (carboxyl terminus of Hsc70-interacting protein) promotes basal and geldanamycin-induced degradation of estrogen receptor-alpha. Mol Endocrinol. 2005; 19:2901-2914. [PubMed: 16037132]

132. Dai Q, Zhang C, Wu Y, McDonough H, Whaley RA, Godfrey V, et al. CHIP activates HSF1 and confers protection against apoptosis and cellular stress. EMBO J. 2003; 22:5446-5458. [PubMed: 14532117]

133. Ballinger CA, Connell P, Wu Y, Hu Z, Thompson LJ, Yin LY, et al. Identification of CHIP, a novel tetratricopeptide repeat-containing protein that interacts with heat shock proteins and negatively regulates chaperone functions. Mol Cell Biol. 1999; 19:4535-4545. [PubMed: 10330192]

134. Tateishi Y, Kawabe Y, Chiba T, Murata S, Ichikawa K, Murayama A, et al. Ligand-dependent switching of ubiquitin-proteasome pathways for estrogen receptor. EMBO J. 2004; 23:48134823. [PubMed: 15538384]

135. Nordmeyer J, Eder S, Mahmoodzadeh S, Martus P, Fielitz J, Bass J, et al. Upregulation of myocardial estrogen receptors in human aortic stenosis. Circulation. 2004; 110:3270-3275. [PubMed: 15533858]

136. Hayward CS, Kalnins WV, Kelly RP. Acute effects of 17 beta-estradiol on ventricular and vascular hemodynamics in postmenopausal women. Am J Physiol Heart Circ Physiol. 2000; 279:H2277-H2284. [PubMed: 11045963]

137. Patten RD, Pourati I, Aronovitz MJ, Alsheikh-Ali A, Eder S, Force T, et al. 17 Beta-estradiol differentially affects left ventricular and cardiomyocyte hypertrophy following myocardial infarction and pressure overload. Journal of cardiac failure. 2008; 14:245-253. [PubMed: 18381189]

138. van Eickels M, Grohe C, Cleutjens JP, Janssen BJ, Wellens HJ, Doevendans PA. 17beta-estradiol attenuates the development of pressure-overload hypertrophy. Circulation. 2001; 104:1419-1423. [PubMed: 11560859]

139. Donaldson C, Eder S, Baker C, Aronovitz MJ, Weiss AD, Hall-Porter M, et al. Estrogen attenuates left ventricular and cardiomyocyte hypertrophy by an estrogen receptor-dependent pathway that increases calcineurin degradation. Circ Res. 2009; 104:265-275. 11p following 75. [PubMed: 19074476]

140. Fliegner D, Schubert C, Penkalla A, Witt H, Kararigas G, Dworatzek E, et al. Female sex and estrogen receptor-beta attenuate cardiac remodeling and apoptosis in pressure overload. Am J Physiol Regul Integr Comp Physiol. 2010; 298:R1597-R1606. [PubMed: 20375266]

141. Pedram A, Razandi M, Lubahn D, Liu J, Vannan M, Levin ER. Estrogen inhibits cardiac hypertrophy: role of estrogen receptor-beta to inhibit calcineurin. Endocrinology. 2008; 149:3361-3369. [PubMed: 18372323]

142. Skavdahl M, Steenbergen C, Clark J, Myers P, Demianenko T, Mao L, et al. Estrogen receptorbeta mediates male-female differences in the development of pressure overload hypertrophy. Am J Physiol Heart Circ Physiol. 2005; 288:H469-H476. [PubMed: 15374829] 
143. Kararigas G, Fliegner D, Gustafsson JA, Regitz-Zagrosek V. Role of the estrogen/estrogenreceptor-beta axis in the genomic response to pressure overload-induced hypertrophy. Physiol Genomics. 2011; 43:438-446. [PubMed: 21325064]

144. Deschamps AM, Murphy E, Sun J. Estrogen receptor activation and cardioprotection in ischemia reperfusion injury. Trends Cardiovasc Med. 2010; 20:73-78. [PubMed: 21130949]

145. Baker L, Meldrum KK, Wang M, Sankula R, Vanam R, Raiesdana A, et al. The role of estrogen in cardiovascular disease. J Surg Res. 2003; 115:325-344. [PubMed: 14697301]

146. Zhai P, Eurell TE, Cotthaus RP, Jeffery EH, Bahr JM, Gross DR. Effects of dietary phytoestrogen on global myocardial ischemia-reperfusion injury in isolated female rat hearts. Am J Physiol Heart Circ Physiol. 2001; 281:H1223-H1232. [PubMed: 11514291]

147. Angele MK, Schwacha MG, Ayala A, Chaudry IH. Effect of gender and sex hormones on immune responses following shock. Shock. 2000; 14:81-90. [PubMed: 10947147]

148. Vornehm ND, Wang M, Abarbanell A, Herrmann J, Weil B, Tan J, et al. Acute postischemic treatment with estrogen receptor-alpha agonist or estrogen receptor-beta agonist improves myocardial recovery. Surgery. 2009; 146:145-154. [PubMed: 19628068]

149. Booth EA, Obeid NR, Lucchesi BR. Activation of estrogen receptor-alpha protects the in vivo rabbit heart from ischemia-reperfusion injury. Am J Physiol Heart Circ Physiol. 2005; 289:H2039-H2047. [PubMed: 15994857]

150. Jeanes HL, Tabor C, Black D, Ederveen A, Gray GA. Oestrogen-mediated cardioprotection following ischaemia and reperfusion is mimicked by an oestrogen receptor (ER)alpha agonist and unaffected by an ER beta antagonist. The Journal of endocrinology. 2008; 197:493-501. [PubMed: 18492815]

151. Wang M, Crisostomo P, Wairiuko GM, Meldrum DR. Estrogen receptor-alpha mediates acute myocardial protection in females. Am J Physiol Heart Circ Physiol. 2006; 290:H2204-H2209. [PubMed: 16415070]

152. Babiker FA, Lips DJ, Delvaux E, Zandberg P, Janssen BJ, Prinzen F, et al. Oestrogen modulates cardiac ischaemic remodelling through oestrogen receptor-specific mechanisms. Acta Physiol (Oxf). 2007; 189:23-31. [PubMed: 17280554]

153. Gabel SA, Walker VR, London RE, Steenbergen C, Korach KS, Murphy E. Estrogen receptor beta mediates gender differences in ischemia/reperfusion injury. J Mol Cell Cardiol. 2005; 38:289-297. [PubMed: 15698835]

154. Wang M, Crisostomo PR, Markel T, Wang Y, Lillemoe KD, Meldrum DR. Estrogen receptor beta mediates acute myocardial protection following ischemia. Surgery. 2008; 144:233-238. [PubMed: 18656630]

155. Wang M, Wang Y, Weil B, Abarbanell A, Herrmann J, Tan J, et al. Estrogen receptor beta mediates increased activation of PI3K/Akt signaling and improved myocardial function in female hearts following acute ischemia. Am J Physiol Regul Integr Comp Physiol. 2009; 296:R972R978. [PubMed: 19211725]

156. Liu H, Pedram A, Kim JK. Oestrogen prevents cardiomyocyte apoptosis by suppressing p38alpha-mediated activation of p53 and by down-regulating p53 inhibition on p38beta. Cardiovasc Res. 2011; 89:119-128. [PubMed: 20724307] 
MAPKKK: ASK1 TPL-2 MLK TAK1 MEKK1 $\underset{\text { REPERFUSION }}{\stackrel{\text { Ischemia/ }}{\longleftarrow}}$
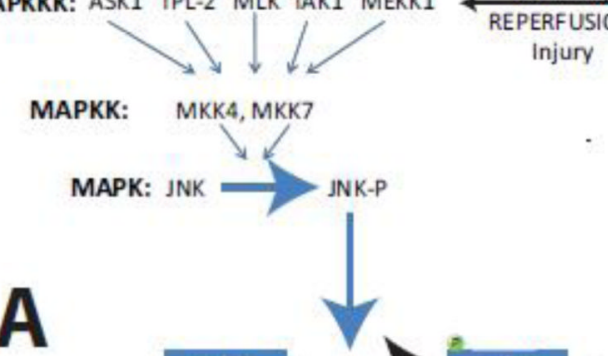

MAPKK:

MKK4, MKK7

MAPK: JNK

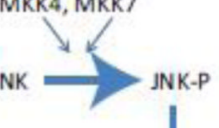

A

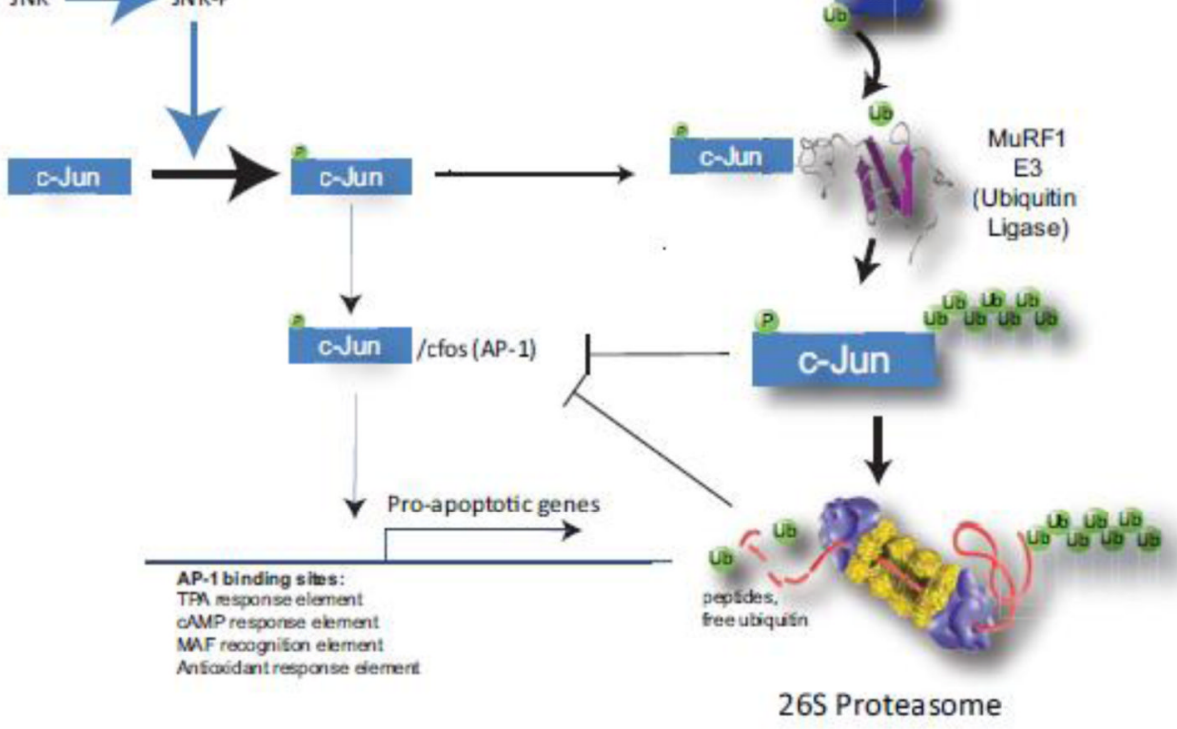

B

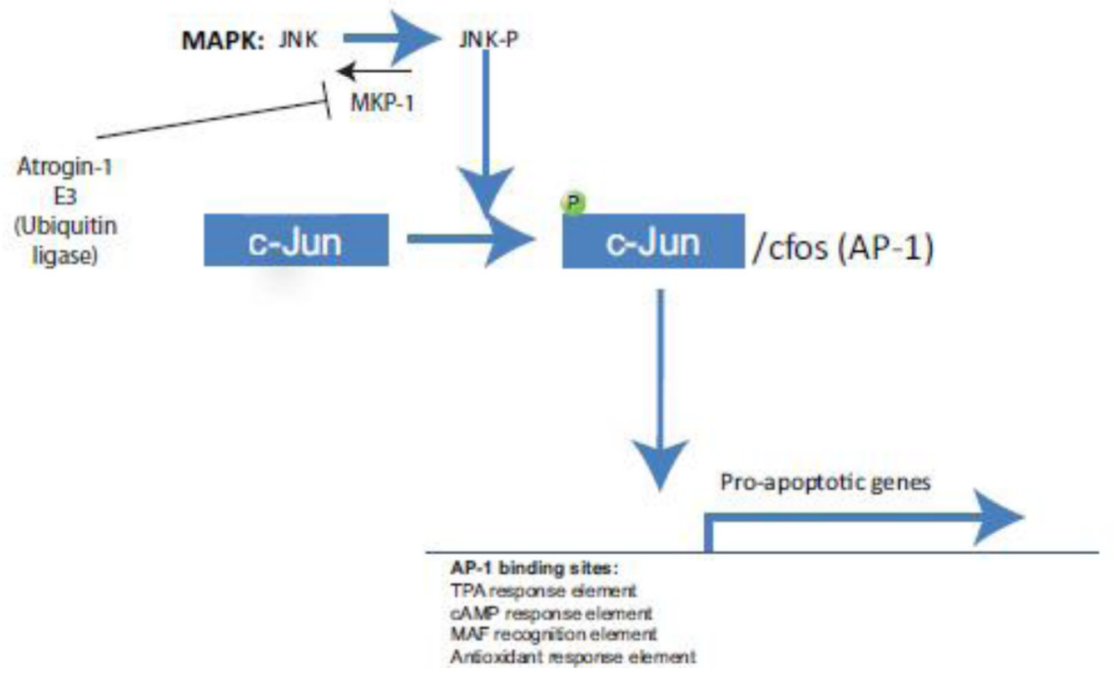

Figure 1. Regulation of JNK signaling by the ubiquitin ligases MuRF1 and aAtrogin-1/MAFbx A. MuRF1 inhibits JNK signaling by preferentially binding phosphorylated c-Jun, polyubiquitinating it and targeting it for degradation by the proteasome in cardiac ischemia reperfusion injury (Summarized from data by Li, et al., 2011 [25]). Increasing cardiomyocyte MuRF1 has recently been shown to be cardioprotective in I/R injury both in vitro and in vivo, in part, by this mechanism, which inhibits JNK-induced apoptosis. B. Atrogin-1/MAFbx enhances JNK signaling by binding and ubiquitinating the JNK inhibitory phosphatase MKP-1 and targeting it for degradation by the proteasome (Summarized from data by Xie, et al., 2009 [26]). Increasing Atrogin-1/MAFbx in culture enhances 
cardiomyocyte susceptibility to I/R injury-induced apoptosis, while inhibiting Atrogin-1/ MAFbx inhibits I/R-induced apoptosis experimentally in vitro. 


\section{FOXO}

Insulin, RTKs, GPCRs, Integrins

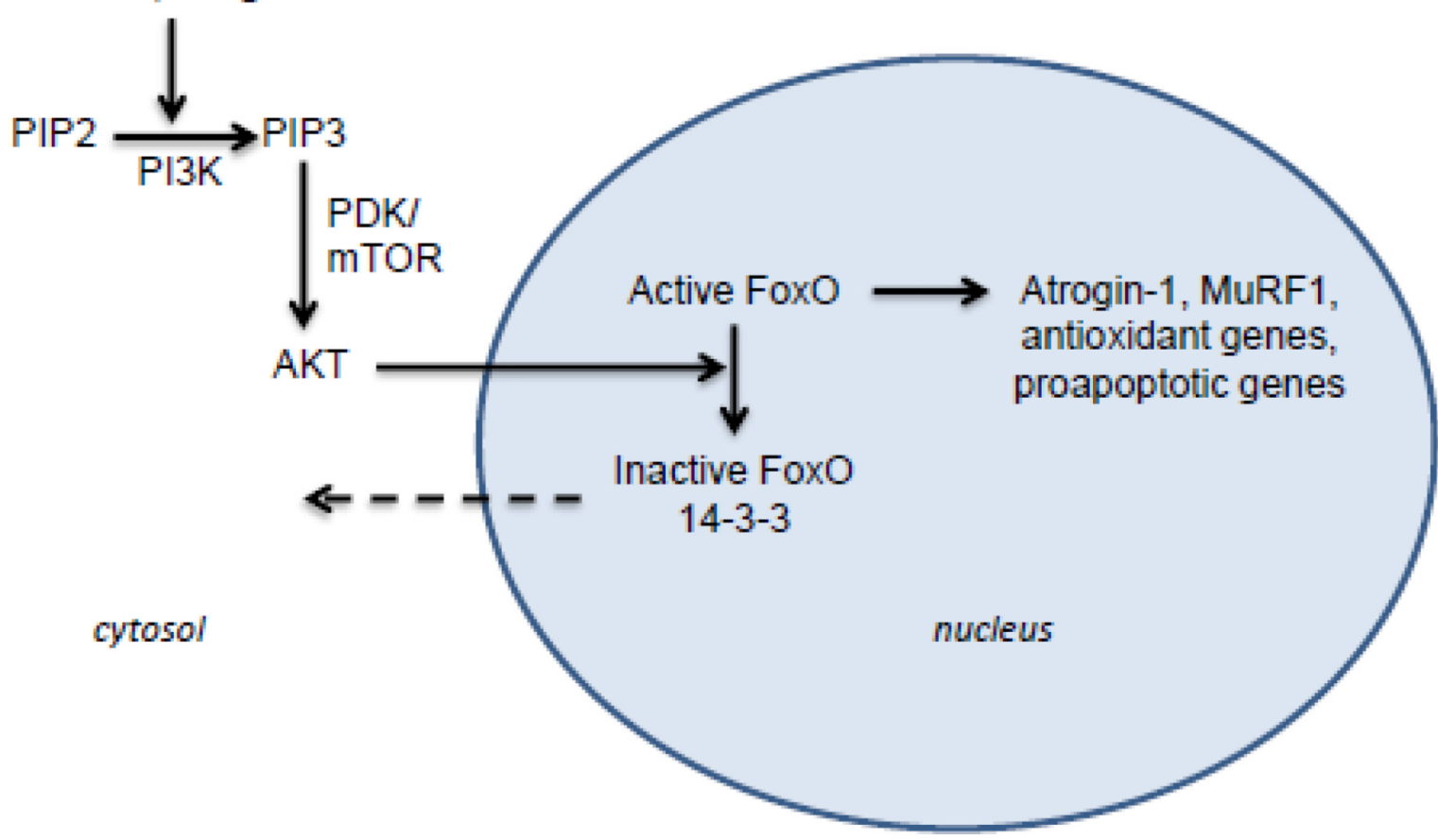

Figure 2. Overview of FoxO signaling

Activation of transmembrane receptors by various stimuli leads to activation of AKT. ATK phosphorylates numerous targets, including FoxO transcription factors. AKTphosphorylated FoxO is inactivated and shuttled to the cytoplasm via association with 14-3-3 proteins. In the absence of AKT activity, FoxO transcription factors transcribe ubiquitin ligases, antioxidants, and proapoptotic genes. 


\section{Degradation:}

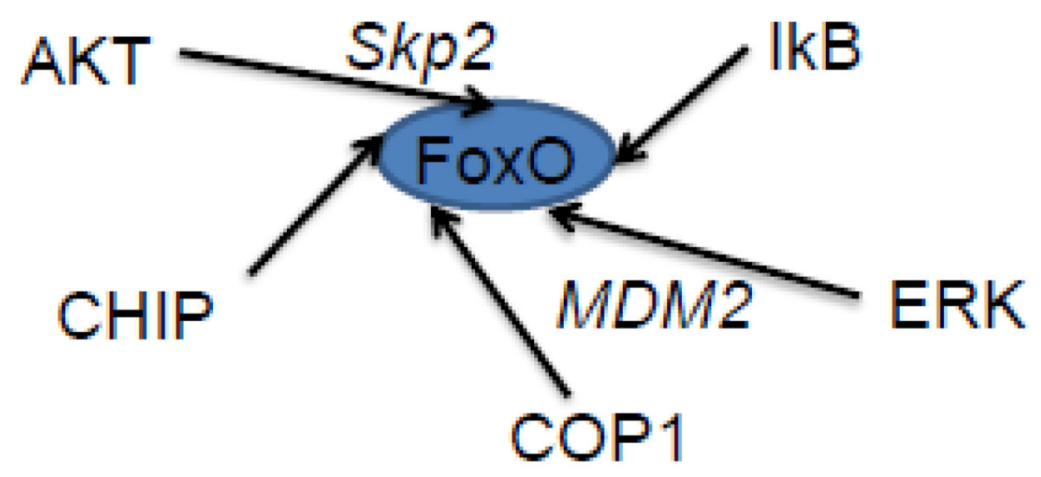

\section{Monoubiquitination:}

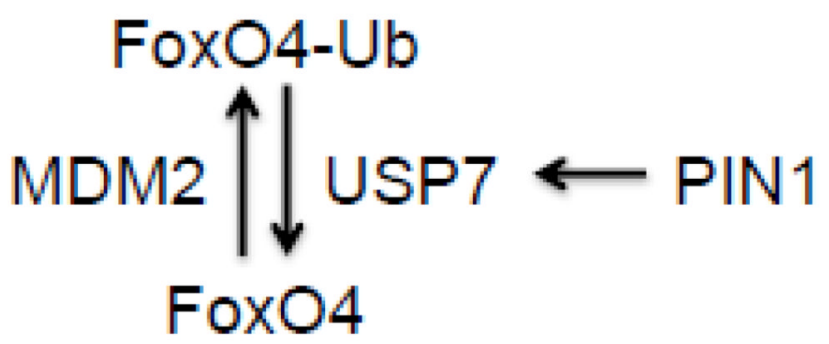

\section{Noncanonical (K63 linked) ubiquitination:}

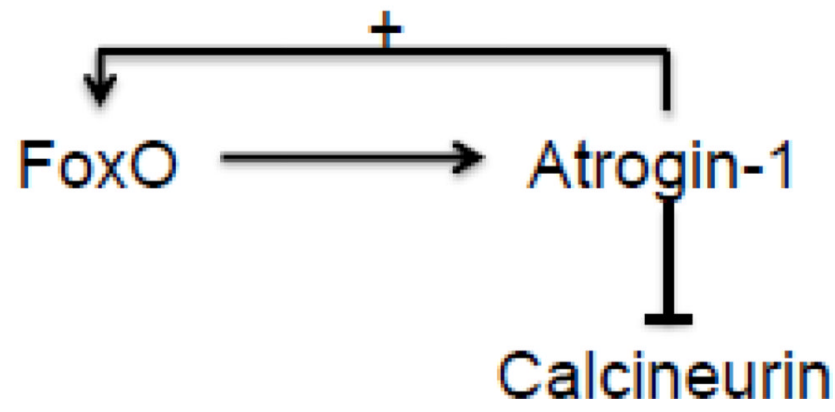

Figure 3. Regulation of FoxO transcription factors by the UPS

A. Multiple ubiquitin ligases can polyubiquitinate and degrade FoxO. However, FoxO activity can be augmented through $\mathbf{B}$. monoubiquitination or C. noncanonical (K63 linked) ubiquitination to regulate its activity as described in the text. 


\section{p53}

Amino Acid \#

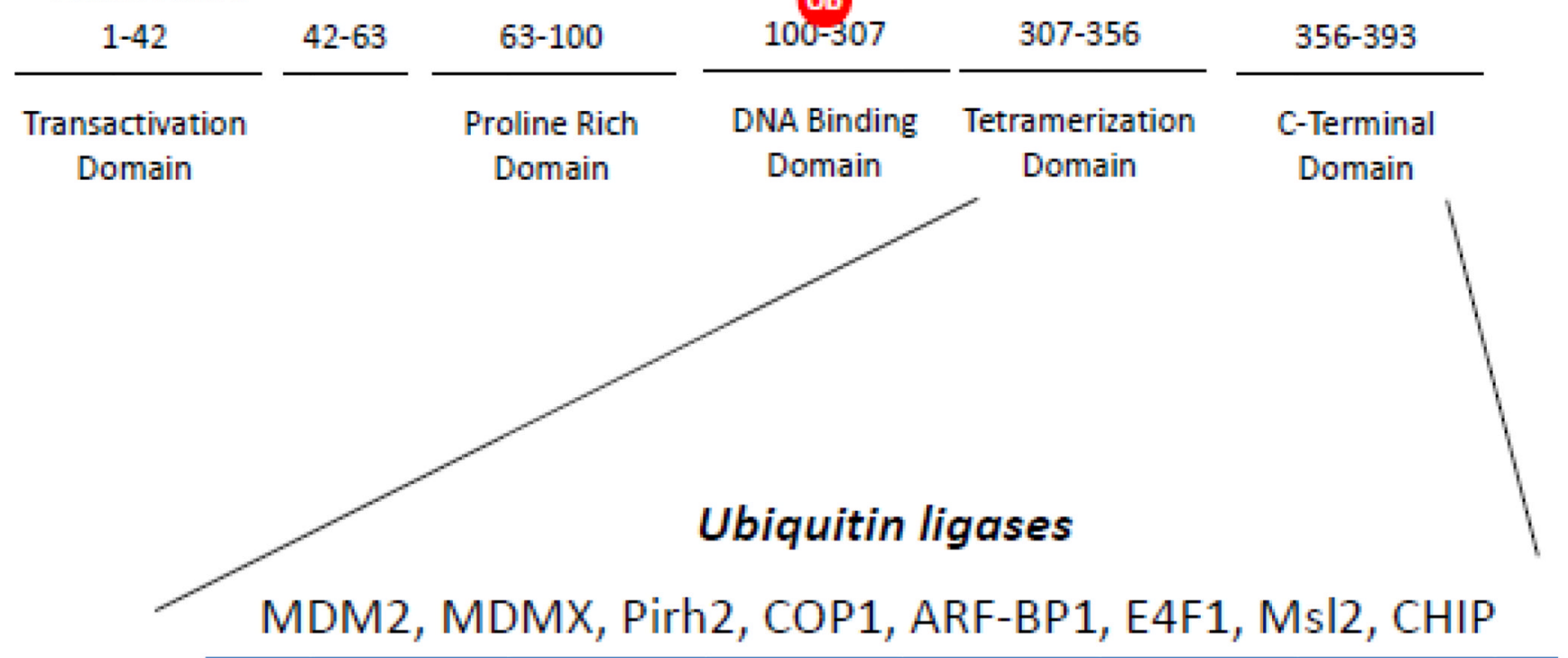

? ? ?

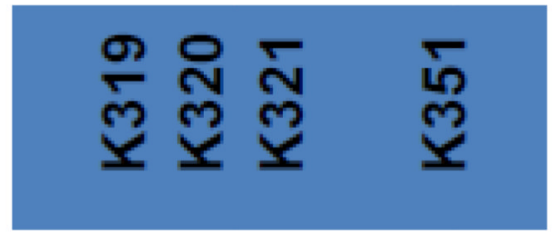

(Ub) $\mathrm{Cb}$ (Ub

Ob $\mathrm{Ob}$ (Ub

Tetramerization

Domain

\section{C-Terminal \\ Domain}

Figure 4. Reported ubiquitin ligases that act upon p53 and the multiple lysines ubiquitinated that regulate steady state protein levels and/or p53 activity

Adapted from Brooks and $\mathrm{Gu}, 2011$ [38]. ?=potential sites that may be ubiquitinated (not reported). 